Respiratory Medicine,

Imperial College

School of Medicine,

National Heart and

Lung Institute,

Hammersmith

Hospital, Du Cane

Road, London

W12 0NN, UK

C L Shovlin

Cancer and Blood

Programme, The

Hospital for Sick

Children, 555

University Avenue,

Toronto, Ontario,

M5G 1X8, Canada

M Letarte

Correspondence to:

Dr C L Shovlin.

\title{
Hereditary haemorrhagic telangiectasia and pulmonary arteriovenous malformations: issues in clinical management and review of pathogenic mechanisms
}

\author{
Claire L Shovlin, Michelle Letarte
}

Hereditary haemorrhagic telangiectasia (HHT, Rendu-Osler-Weber syndrome) exemplifies an important group of diseases which have catalysed advances in the understanding of fundamental pathophysiological mechanisms. In this paper areas of clinical management of HHT are discussed and the molecular pathogenesis is reviewed. The first section is aimed at all clinicians and concentrates on the recognition of a disorder in which silent cerebral and pulmonary involvement may be life threatening
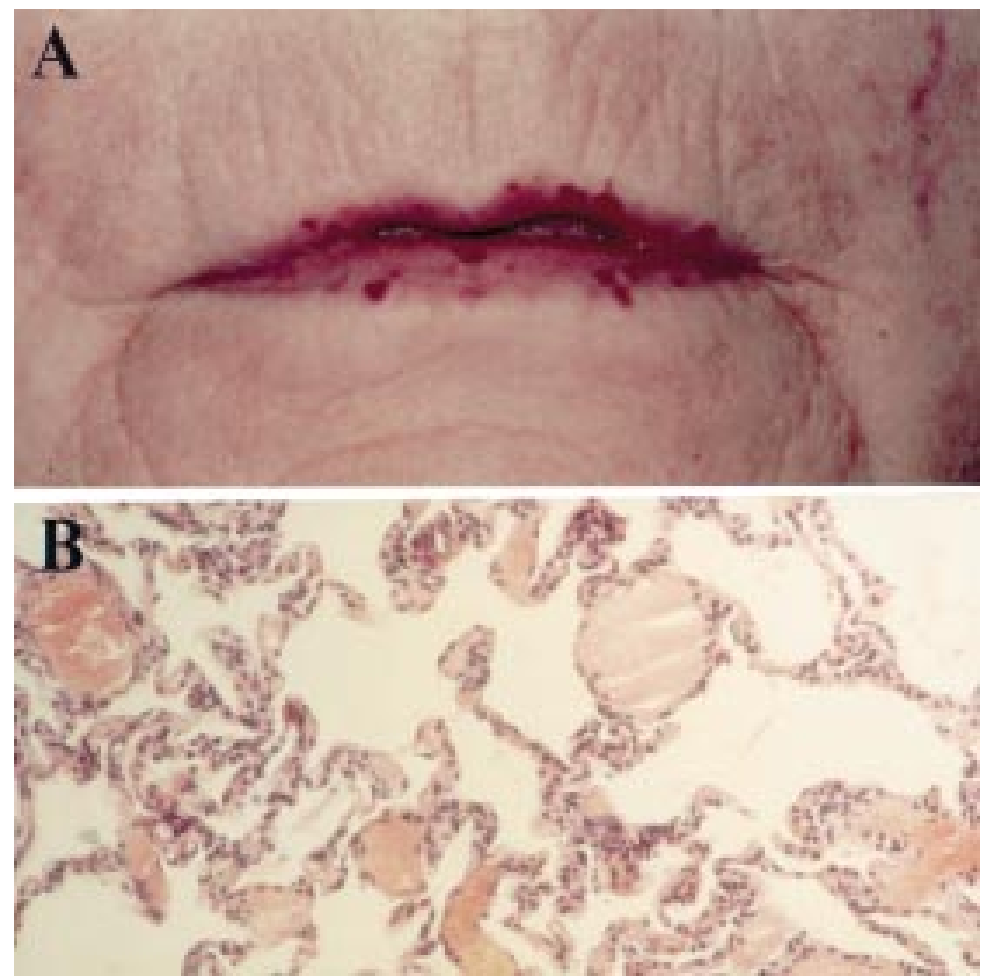

Figure 1 Hereditary haemorrhagic telangiectasia (HHT). (A) Mucocutaneous telangiectasia on the lips of a patient with HHT. In these simple telangiectases, thin walled endothelial cell lined vessels resembling dilated post capillary venules connect apparently normal capillaries and draining venules, with a high frequency of direct arteriovenous communications. ${ }^{36}$ (B) Histology of microscopic PAVMs. Haemotoxylin and eosin stained slide taken from an open lung biopsy specimen displaying dilated vascular structures in place of normal corner vessels. These were not visible radiologically, although they caused hypoxaemia and a right-to-left shunt. ${ }^{7}$ As in mucocutaneous telangiectases, ${ }^{3}$ it is thought that larger lesions (see fig 2) may arise from microscopic PAVMs by a process of remodelling. if left untreated. Recent data concerning the diagnostic and treatment modalities for pulmonary arteriovenous malformations (PAVMs) are also reviewed, and the growing concern that many patients with HHT may have small or residual PAVMs is highlighted. The paucity of good longitudinal data on these patients and others with different forms of HHT highlights the need for further clinical studies. In the second section the results of molecular research which suggests a role for receptors and ligands of the transforming growth factor (TGF) $-\beta$ superfamily in the pathogenesis of this vascular disease are discussed. The means by which such information may relate to the clinical heterogeneity observed in HHT are specifically addressed, and more fundamental questions such as how reduced cell surface expression of endoglin predisposes a patient to develop PAVMs are also discussed.

Hereditary haemorrhagic telangiectasia The classical patient with the vascular disorder hereditary haemorrhagic telangiectasia (HHT) has nose bleeds, dilated blood vessels over the lips and finger tips, and gastrointestinal bleeding in later life. However, this clinical scenario represents only one of the presentation patterns of HHT. ${ }^{1}{ }^{2}$ It is now recognised that, in addition to microscopic mucocutaneous telangiectases derived from post capillary venules (fig 1A), ${ }^{3}$ HHT leads to the development of larger abnormal vascular structures at other sites. Arteriovenous malformations in the pulmonary, cerebral, and hepatic circulations account for some of the most devastating clinical complications of the disease.

The autosomal dominant inheritance pattern of HHT has enabled identification of the underlying genetic defects, prompting increased scientific interest in the disorder. Mutations in at least two genes have been shown to be associated with HHT in different families: endoglin on chromosome $9,{ }^{4}$ and $A L K-1$ (activin receptor-like kinase 1) on chromosome $12 .{ }^{5}$ Both genes encode endothelial cell transmembrane proteins that can be defined as components of the receptor complexes for growth factors of the TGF- $\beta$ super- 
Table 1 Clinical features of HHT

\begin{tabular}{|c|c|c|c|c|}
\hline Site & Incidence & Type of lesion & Presentation pattern & Treatment regimes \\
\hline Nasal mucosa & $>90 \%$ & Telangiectasia & $\begin{array}{l}\text { Nose bleeds are usually the first } \\
\text { manifestation of HHT, frequently } \\
\text { commencing in childhood }\end{array}$ & $\begin{array}{l}\text { 1) Routine therapy: packing, } \\
\text { humidification, treatment with iron and } \\
\text { transfusions when needed. } \\
\text { Oestrogen/progesterone therapy } \\
\text { proposed (in view of possible induction } \\
\text { of squamous metaplasia) but no benefit } \\
\text { in only controlled trial. }{ }^{15} \text { 2) Laser } \\
\text { treatment successful. Argon and KTP } \\
\text { lasers which use wavelengths maximally } \\
\text { absorbed by haemoglobin }{ }^{16}{ }^{17} \text { often } \\
\text { preferred to Nd-YAG }{ }^{18} \text { which carries a } \\
\text { higher risk of cartilage absorption and } \\
\text { septal perforation. } 3 \text { ) Surgery, such as } \\
\text { septal dermoplasty to replace thin nasal } \\
\text { mucosa with a tougher skin graft, is } \\
\text { successful in expert hands, }{ }^{19} \text { though } \\
\text { vessels regrow. } 4 \text { ) Other. Therapeutic } \\
\text { embolisation may be difficult because } \\
\text { of extensive anastomoses; cauterisation } \\
\text { has only a limited role. }{ }^{17}\end{array}$ \\
\hline Mucocutaneous & $50-80 \%$ & Telangiectasia & $\begin{array}{l}\text { Increase with age. Main concerns are } \\
\text { cosmetic. May haemorrhage }\end{array}$ & $\begin{array}{l}\text { Generally not indicated, but argon laser } \\
\text { therapy can be used }{ }^{17}\end{array}$ \\
\hline Gastrointestinal tract & $11-40 \%$ & $\begin{array}{l}\text { Telangiectasia, aneurysms and } \\
\text { AVMs }^{20}\end{array}$ & $\begin{array}{l}\text { Onset generally over } 30 \text { years: iron } \\
\text { deficiency anaemia, occasionally acute } \\
\text { gastrointestinal haemorrhage }\end{array}$ & $\begin{array}{l}\text { Iron supplementation and transfusion } \\
\text { are the mainstay of treatment. } \\
\text { Oestrogen-progesterone, }{ }^{21} \text { and laser } \\
\text { therapy }{ }^{22} \text { beneficial. The role of } \\
\text { antifibrinolytics is unclear. }{ }^{23-25}\end{array}$ \\
\hline Pulmonary & $\geqslant 20 \%$ & Discussed in text. & & \\
\hline Cerebral & $15 \%$ & Discussed in text. & & \\
\hline Hepatic & $8-16 \%$ & $\begin{array}{l}\text { Dilated sinusoids and peri-portal } \\
\text { veins; AVMs including hepatic } \\
\text { artery-hepatic vein and portal } \\
\text { vein-hepatic vein communications. } \\
\text { Associated fibrosis }{ }^{26}\end{array}$ & $\begin{array}{l}\text { Usually silent. Hepatic artery-hepatic } \\
\text { vein AVMs: hyperdynamic circulation. }{ }^{27} \\
\text { Portasystemic shunts: ascites }{ }^{28} \text { and } \\
\text { encephalopathy }{ }^{29}\end{array}$ & $\begin{array}{l}\text { Diagnosis: angiography, CT, MRI or } \\
\text { Doppler sonography. }{ }^{30} \text { Treatment: } \\
\text { embolisation }^{27} \text { but not without risk }{ }^{31}{ }^{32} \text {; } \\
\text { liver transplantation may be needed }{ }^{33}\end{array}$ \\
\hline Conjunctival & Up to $45 \%$ & Telangiectasia & $\begin{array}{l}\text { Usually silent. May have "bloody } \\
\text { tears"34 } 35\end{array}$ & \\
\hline
\end{tabular}

$\mathrm{AVM}=$ arteriovenous malformation.

Other sites involved more rarely include spinal, renal, ${ }^{36}$ coronary, ${ }^{37}$ bony, ${ }^{38}$ urogenital, splenic,,${ }^{30}$ and retinal ${ }^{39}$ vascular beds.

Incidence data are derived from references 1,2 , and 8 except where stated.

family. This suggests that disease pathogenesis is likely to result from perturbation of physiological effect(s) of these growth factors in vascular development or homeostasis. At the present time, the factors implicated and the mechanisms which regulate their action remain speculative. Relevant data are discussed further in the final section of this review, to which the non-clinical reader is referred directly.

\section{CLINICAL ASPECTS OF HHT}

HHT is more common than previously appreciated, with prevalence rates exceeding one in 10000 in some regions. ${ }^{8-11}$ The disease displays age related penetrance, with manifestations developing throughout life and varying between affected individuals, even individuals from the same family. Heterozygotes account almost exclusively for the patient population: there are very few reports of probable homozygous cases. ${ }^{12-14}$

The common clinical manifestations of HHT are summarised in table 1 which also provides an overview of the presentation patterns and treatments for the manifestations that are usually managed by appropriate specialists (epistaxis, mucocutaneous telangiectasia, and gastrointestinal lesions); further information may be found in excellent recent reviews. ${ }^{12}$ A significant proportion of patients with HHT have pulmonary and cerebral vascular involvement. These manifestations differ from other common sites of involvement since silent lesions may cause considerable morbidity and mortality if left untreated.
The key to appropriate management of patients with HHT is to be alert to the possibility of additional visceral involvement and hence the importance of establishing a diagnosis. This point needs to be considered by the physician as individuals presenting with HHT are often unaware that they have a familial disease. Current clinical diagnostic criteria require the presence of three out of four key features for a definitive diagnosis-namely, spontaneous recurrent epistaxis, telangiectases at characteristic sites, a visceral manifestation, and an affected first degree relative. ${ }^{40}$ To reduce the number of cases overlooked and deprived of suitable screening regimes, the label of "suspected HHT" should be used if two features are present, and particularly in the presence of PAVMs which are rare in patients without HHT. $^{40}$ Since HHT may present to a number of clinical specialities, the significance of a particular presentation is often overlooked. ${ }^{41}$

\section{CEREBROVASCULAR MALFORMATIONS AND HHT}

Cerebral manifestations including telangiectases, venous malformations, and arteriovenous malformations (CAVMs) are underrecognised in patients with HHT. Cerebral involvement is usually said to affect $5-10 \%$ of patients with $\mathrm{HHT}^{18}$ but a much higher incidence is seen when asymptomatic patients are screened. ${ }^{42}$

The highest complication rate is observed in high flow CAVMs which may present with headache, epilepsy, ischaemia (due to a vascular steal effect), or haemorrhage. Symptomatic lesions may be treated by microsurgical exci- 
sion, stereotactic radiotherapy for lesions less than $3 \mathrm{~cm}$ in diameter, and embolisation. ${ }^{12}$ There are no trials comparing embolisation with other forms of treatment but a recent review suggests that patients offered stereotactic radiotherapy fared less well in terms of immediate mortality, obliteration of the lesion, and post-intervention neurological deficits than patients treated by microsurgery. ${ }^{43}$

There has been considerable debate about the optimal therapy for asymptomatic CAVMs. The natural history of HHT associated CAVMs is not entirely clear though it is usually assumed to be equivalent to non-HHT CAVMs. A risk of haemorrhage of $2 \%$ per annum, varying with certain features of the lesion, ${ }^{44}{ }^{45}$ is generally used as the basis of careful risk-benefit analyses. These analyses suggest that in asymptomatic patients the risks of haemorrhage with expectant treatment outweigh the risks of intervention, particularly in young patients. ${ }^{46}$ However, the risk assessment for individual patients must consider the patient's age, specific features of the lesion, and particularly the available therapeutic expertise. $^{2}{ }^{46}$

Since intervention may be recommended for asymptomatic patients, some centres offer screening programmes for families with HHT using intravenous digital subtraction angiography (DSA). ${ }^{24}$ This avoids the morbidity from conventional cerebral angiography although the limitations of this relatively noninvasive technique have to be recognised.

\section{Pulmonary arteriovenous malformations and HHT}

OVERVIEW

More than $20 \%$ of patients with HHT develop pulmonary arteriovenous malformations (PAVMs) which range from diffuse telangiectases (fig $1 \mathrm{~B})^{48-50}$ to large complex structures consisting of a bulbous aneurysmal sac between dilated feeding arteries and draining veins (fig 2). ${ }^{51}$ Around $95 \%$ of feeding arteries come from the pulmonary rather than systemic circulation. $^{50}$ Since approximately $70 \%$ of PAVMs occur in patients with HHT, ${ }^{52-54}$ their detection should prompt a thorough review of the patient and his or her family. Multiple lesions are particularly suggestive of an association with HHT. ${ }^{52} 5355$

PAVMs tend to increase in size, ${ }^{505657}$ especially if multiple, ${ }^{56}$ and rarely regress spontaneously. ${ }^{57}$ The mortality rate in historical reviews of untreated but usually symptomatic patients with PAVMs over periods of 15 years or less ranges from $4 \%$ to $22 \% 5255565859$ and, in severe cases, up to $40 \% .^{60}$ Complications are more common when HHT is present. ${ }^{61}$ The abnormal vessels may bleed into a bronchus or the pleural cavity, sometimes with a fatal outcome. ${ }^{606}{ }^{63}$ However, it is the functional consequences of the direct communications between pulmonary and systemic circulations, bypassing the capillary bed, that most commonly cause problems. Such rightto-left shunts cause hypoxaemia and the absence of a filtering capillary bed allows para- doxical embolism of particulate matter which can reach the systemic arteries, causing clinical sequelae, particularly in the cerebral circulation.

These processes account for the clinical features on presentation (table 2). It should be noted that dyspnoea was common $(47 \%)$, though many patients tolerate hypoxaemiaeven exercise aggravated hypoxaemia-well, reflecting their low pulmonary vascular resistance and ability to generate supranormal cardiac outputs ${ }^{64-66}$ which may increase further on exercise. ${ }^{67}$ Haemoptysis was seen in $11 \%$. Up to $50 \%$ of patients had no respiratory complaints on presentation despite physical signs (such as cyanosis, clubbing, or a vascular bruit) or an abnormal chest radiograph. Most importantly, many patients had minimal respiratory symptoms when presenting with neurological complications of PAVMs (transient ischaemic attacks, strokes and cerebral abscesses). ${ }^{5255}$ PAVMs accounted for two thirds of HHTrelated neurological presentations in one series $^{68}$ and they carry a significant mortality. ${ }^{69}$

It is recommended that patients with PAVMs should receive antibiotic prophylaxis prior to dental and surgical interventions to reduce embolic abscesses, ${ }^{83-85}$ although there is no direct evidence of benefit. Formal treatment of PAVMs by periangiographic embolisation techniques or surgery is required to alter radically the long term prognosis for patients with PAVMs.

DIAGNOSIS OF PAVM

Pulmonary angiography is required for therapeutic embolisation and is also mandatory to determine the position and structure of abnormal vascular lesions prior to surgical treatment. Angiography is labour, cost and radiation intensive and its use should be limited to individuals in whom non-invasive diagnostic tests strongly suggest the presence of PAVMs. The methods used depend upon local experience but several recently published studies are worth reviewing.

Initial investigations

Chest radiographs-Moderate sized PAVMs appear as rounded, well circumscribed lesions (fig 2), often with associated band shaped shadows resulting from dilated feeding and draining vessels. The intensity of shadowing may be diminished or enhanced respectively by the Valsalva and Muller manoeuvres. ${ }^{86}$ Patients with PAVMs often present with an abnormality on the chest radiograph, ${ }^{55}$ and this may have led to an overestimate of the frequency of radiographic abnormalities at presentation; it is now recognised that a normal posterioranterior and lateral chest radiograph does not rule out PAVMs (table 3), ${ }^{42} 56$ particularly in patients with small or diffuse malformations. Assessment of hypoxaemia-Unexplained and often profound hypoxaemia is the hallmark of large PAVMs, but there are additional features that may help to establish more specific diagnostic tests. Further desaturation on assuming the upright posture, orthodeoxia, is common in patients with PAVMs, ${ }^{91}$ due prima- 


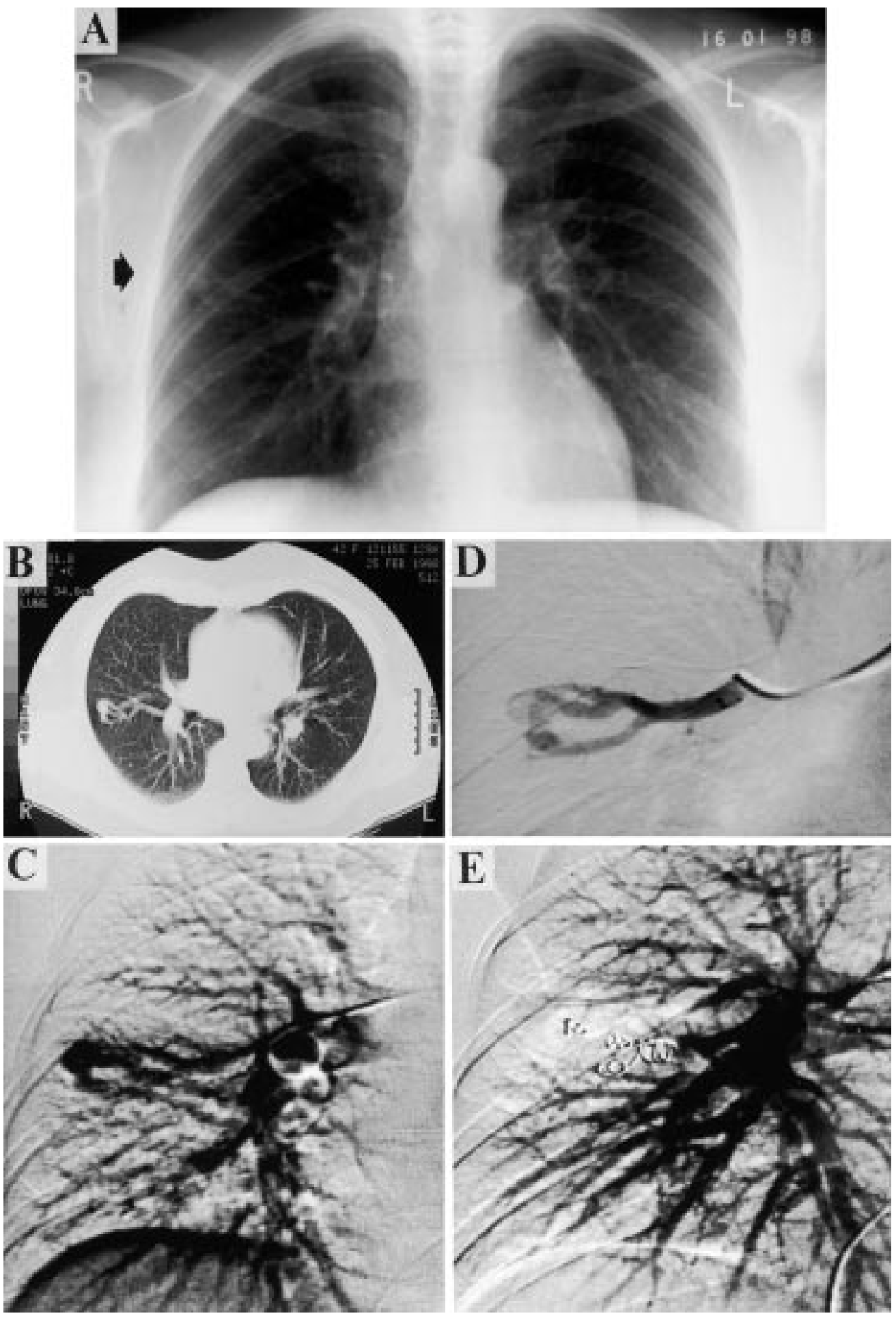

Figure 2 A PAVM from diagnosis to treatment. A 42 year old woman presented with lethargy and a history of previous nose bleeds. A chest radiograph $(A)$ and CT scan (B) suggested the presence of a PAVM. She was marginally hypoxaemic ( $\mathrm{PaO}_{2} 11.4 \mathrm{kPa}$ on air) with no orthodeoxia. Her right-to-left shunt measured by $100 \%$ oxygen was 6-8\%. Angiography confirmed a single lesion in the right mid zone $(C)$. Selective angiography $(D)$ revealed a complex structure with three feeding arteries and a single draining vein. The feeding vessels were embolised with five metallic coils (E). Two months after embolisation there was significant improvement in oxygenation $\left(\mathrm{PaO}_{2} 13.5 \mathrm{kPa}\right)$.

rily to a gravity induced increase in flow through basally situated shunts (approximately $70 \%$ of PAVMs), ${ }^{505253587175}$ which increases the right-to-left shunt. ${ }^{92}$ Data on the effect of exercise on shunt flow and hypoxaemia are contradictory. ${ }^{73} 93$

The detection of hypoxaemia lacks specificity as a diagnostic test (table 3$)^{42}$ but it can identify patients worthy of further investigation. In 66 patients who had undergone embolisation, the presence and extent of residual PAVM disease was related to oxygen saturation (despite the imprecision of pulse oximetry $^{94}{ }^{95}$ ) with the patients erect and supine and on maximal exercise, and to the change in oxygen saturation between being erect and 
Table 2 Symptoms and signs of PAVMs at presentation in major series. Many patients will have symptoms, stigmata or a family history of HHT

\begin{tabular}{|c|c|c|c|c|c|}
\hline & $\begin{array}{l}\text { Incidence } \\
(\%)\end{array}$ & $\begin{array}{l}\text { Mean } \\
(\%)\end{array}$ & No. of patients & References & Comments \\
\hline \multicolumn{6}{|l|}{ Respiratory } \\
\hline Dyspnoea on exertion & $27-71$ & 47 & 427 & $52,53,55,56^{\mathrm{TM}}, 57,70,71^{\star}, 72-76^{\mathrm{TM}}, 77$ & \\
\hline Chest pain & $6-17$ & 12 & 132 & $52,70,73$ & \\
\hline Haemoptysis & $4-18$ & 11 & 413 & $\begin{array}{l}52,53,55,56^{\mathrm{TM}}, 57,59,70,71^{\star}, 74-76^{\mathrm{TM}}, \\
78\end{array}$ & $\begin{array}{l}\text { Particularly if systemic rather than } \\
\text { pulmonary arterial supply }{ }^{79} 80\end{array}$ \\
\hline Haemothorax & $0-2$ & $<1$ & 129 & $53,74,76^{\mathrm{TM}}$ & Probably increased in pregnancy ${ }^{62} 6381$ \\
\hline Asymptomatic & $25-58$ & 49 & 197 & $52,56^{\mathrm{TM}}, 71^{\star}, 72-74,76^{\mathrm{TM}}, 82$ & \\
\hline Cyanosis & $9-73$ & 30 & 209 & $52,56^{\mathrm{TM}}, 71^{\star}, 72,74,76^{\mathrm{TM}}, 82$ & \\
\hline Clubbing & $6-68$ & 36 & 201 & $52,55,56^{\mathrm{TM}}, 57,73,74,76^{\mathrm{TM}}$ & \\
\hline Bruit & $25-58$ & 49 & 197 & $52,55,56^{\mathrm{TM}}, 70,73,82$ & \\
\hline \multicolumn{6}{|l|}{ Neurological } \\
\hline Cerebral abscesses & $0-25$ & 9 & 302 & $52,53,58,71^{\star}, 74-76^{\mathrm{TM}}, 77$ & \\
\hline Clinical TIA/stroke & $11-55$ & 24 & 335 & $52-54,70,71^{\star}, 73-76^{\mathrm{TM}}, 77$ & Asymptomatic incidence possibly double $\mathrm{e}^{78}$ \\
\hline Migraine & $4-38$ & 28 & 150 & $53,74,75$ & \\
\hline
\end{tabular}

TIA $=$ transient ischaemic attack.

тм: The 32 cases reported in reference 76 and 27 cases in reference 56 include a high proportion of individuals diagnosed by screening of asymptomatic HHT family members; ${ }^{\star}$ indicates a childhood series of 31 patients. ${ }^{71}$ In view of overlapping series, data from reference 59 were not presented as all cases were reported in reference 52 , and data in reference 82 were reported only where not stated in reference 75.

supine. ${ }^{89}$ Oxygen saturation with the patient erect was the best predictor of the presence or absence of disease, though sensitivity and specificity were again too low to recommend it as the sole diagnostic screening test (table 3 ).

\section{Confirmatory studies}

Abnormal architecture-Helical CT scanning with three-dimensional reconstructions conveniently identifies small, multiple lesions; it can also identify thrombosed ${ }^{8896}$ and, with contrast, recanalised structures. ${ }^{77}$ It exposes patients at risk of recurrent disease to a significant dose of radiation, and misdiagnoses have been reported. ${ }^{97}$ At present NMR screening is less effective than computed tomographic (CT) scanning or pulmonary angiography as small PAVMs with rapid blood flow are not visualised, ${ }^{98}$ but methodology is improving.

Intravenous digital subtraction angiography (DSA) of pulmonary arteries is performed prior to formal catheter pulmonary angiography in some centres to visualise the pulmonary vasculature, particularly as part of an outpatient screening programme. ${ }^{42}$ However, this method is less likely to detect certain lesions than formal angiographic studies. ${ }^{42}$

Detection of right-to-left shunts-In normal individuals the right-to-left shunt is less than $2 \%$ of the cardiac output ${ }^{99} 100$ and ascribed to "post- pulmonary" shunting due to the mixing of pulmonary venous blood with deoxygenated blood from bronchial, mediastinal, and thebesian veins. The flow through right-to-left shunts is usually expressed as a fraction of total flow (Q்s/QT) and may be calculated from the reduction in arterial oxygenation or by anatomical methods using particles $7-11 \mathrm{~mm}$ in diameter which normally impact in pulmonary capillaries but pass through large calibre shunt vessels.

$100 \%$ inspired oxygen breathing method: Calculating the shunt from the arterial oxygen tension after breathing $100 \%$ oxygen for 20 minutes has been considered the gold standard for non-invasive methods of estimating the size of the shunt. ${ }^{99}$ Effects of ventilation-perfusion inequalities should be overcome since blood derived from poorly ventilated alveoli will be fully saturated, though it should be noted that this method will also detect post-pulmonary shunting. The anatomical intrapulmonary shunt may be underestimated if microscopic arteriovenous malformations are participating in gas exchange, ${ }^{101}$ although such shunts may not be treatable. Disadvantages include the requirements for a mask and bag to give $100 \%$ oxygen, arterial blood gas sampling and difficulties in calibrating the oxygen electrode for high oxygen tensions using blood tono-

Table 3 Comparison of findings from different methods used to detect PAVMs

\begin{tabular}{|c|c|c|c|c|c|c|c|c|c|}
\hline & \multicolumn{4}{|c|}{ Patient population } & \multirow[b]{2}{*}{ Sensitivity } & \multirow[b]{2}{*}{ Specificity } & \multirow{2}{*}{$\begin{array}{l}\text { No. of PAVMs } \\
\text { missed compared } \\
\text { with angiography }\end{array}$} & \multirow{2}{*}{$\begin{array}{l}\text { No. where PAVMs not } \\
\text { detected at } \\
\text { angiography }\end{array}$} & \multirow[b]{2}{*}{ Reference } \\
\hline & Total & $\begin{array}{l}\text { PAVM } \\
\text { present }\end{array}$ & $\begin{array}{l}\text { No } \\
P A V M\end{array}$ & Unknown & & & & & \\
\hline \multicolumn{10}{|l|}{ Radiology } \\
\hline Chest radiography & 98 & 12 & 84 & 2 & $83 \%(52-98)$ & $92 \%(84-97)$ & $2(2 \%$ of pts $)$ & $7(7 \%$ of pts $) \dagger$ & 42 \\
\hline CT scans & $40^{\mathrm{TM}}$ & 40 & 0 & 0 & & & $\begin{array}{l}\text { 2/109 PAVMs } \\
(2 \%)\end{array}$ & $\begin{array}{l}\text { 42/109 PAVMs } \\
(39 \%)\end{array}$ & 88 \\
\hline \multicolumn{10}{|l|}{ Hypoxaemia } \\
\hline $\mathrm{PaO}_{2}$ & 98 & 12 & 84 & 2 & $67 \%(35-90)$ & $61 \%(50-71)$ & $4(4 \%$ of pts) & $33(34 \%$ of pts $) \dagger$ & 42 \\
\hline $\mathrm{SaO}_{2}$ erect $\leqslant 96 \%$ & 66 & 66 & 0 & 0 & $73 \%$ & $35 \%$ & & $0^{\star}$ & 89 \\
\hline \multicolumn{10}{|l|}{ R-L shunts } \\
\hline $\begin{array}{l}100 \% \text { oxygen } \\
\text { shunt }>5 \%\end{array}$ & 37 & 8 & 28 & 1 & $88 \%(47-100)$ & $72 \%(51-87)$ & $1(2.7 \%$ of pts $)$ & $8 / 15(53 \%$ of pts $) \dagger$ & 42 \\
\hline $\begin{array}{l}\text { Contrast } \\
\text { echocardiography } \\
{ }^{99 \mathrm{~m}} \text { Tc scan }\end{array}$ & 21 & 15 & 6 & 0 & & & & $6(28 \%$ of pts $)$ & 90 \\
\hline shunt $>5 \%$ & 66 & 66 & 0 & 0 & $68 \%$ & $72 \%$ & & $0^{\star}$ & 89 \\
\hline shunt $>3.5 \%$ & 66 & 66 & 0 & 0 & $87 \%$ & $61 \%$ & & $0^{\star}$ & 89 \\
\hline
\end{tabular}

$\mathrm{PaO}_{2}=$ arterial oxygen tension; $\mathrm{SaO}_{2}=$ arterial oxygen saturation.

${ }^{\star}$ Method of patient ascertainment in reference 89 .

TThe angiographic data were obtained by intravenous rather than pulmonary artery catheter DSA: the number of "overdiagnosed" PAVMs may therefore include some PAVMs missed by this less sensitive angiographic method. Data obtained from HHT family screening programmes ${ }^{42}{ }^{90}$ or known PAVM patients. ${ }^{88} 89$ 
metry or commercially available sealed buffer solutions. In the absence of right heart catheterisation mixed venous oxygen content is usually estimated. The normal arteriovenous oxygen content $\left(\mathrm{A}-\mathrm{VO}_{2}\right)$ difference is $5 \mathrm{ml} /$ $100 \mathrm{ml}$. Recognising that patients with an $\mathrm{A}-\mathrm{V}$ shunt are likely to have an increased cardiac output, and that a lower $\mathrm{A}-\mathrm{VO}_{2}$ difference of $3.5 / 100 \mathrm{ml}$ may be more appropriate for this situation, some centres calculate the shunt for both normal and high cardiac outputs (using $\mathrm{A}-\mathrm{VO}_{2}$ differences of $5 \mathrm{ml} / 100 \mathrm{ml}$ and 3.5/ $100 \mathrm{ml}$, respectively), with the final shunt fraction given as a range between the two values (as in fig 2). Using $100 \%$ inspired oxygen, a rightto-left shunt of more than $5 \%$ is considered abnormal.

Radionuclide scanning: following intravenous injection of technetium-99m $\left({ }^{99 m} \mathrm{Tc}\right)-$ labelled albumin microspheres or macroaggregates, the right-to-left shunt can be calculated by comparing the quantity reaching the systemic circulation with the total quantity received. ${ }^{102} 103$ Shunts of up to $3.5 \%$ are detected in normal subjects. ${ }^{102}$ Recent data from one institution with extensive experience using this method indicated that, in patients who had undergone embolisation of PAVMs, a shunt measurement of $>3.5 \%$ had $87 \%$ sensitivity and $61 \%$ specificity for the presence of residual disease. ${ }^{89}$ However, suitable facilities are not always available.

Contrast echocardiography can be used to assess the presence of right-to-left shunting, although currently the shunt cannot be quantified by this method. Microbubbles generated by intravenously injected echocontrast should be lost on passage through the normal pulmonary capillary bed; the appearance of echoes in the left ventricle indicates the presence of a right-to-left shunt, a delay of $2-5$ seconds indicating an intrapulmonary shunt rather than an intracardiac shunt in which left ventricular echoes appear almost instantly. ${ }^{104}$ Contrast echocardiography may be too sensitive for clinical use, however (see below).

Comparisons of non-invasive screening procedures and correlation with angiographic confirmation of PAVMs

Non-invasive methods have rarely been compared, although an excellent correlation was obtained for right-to-left shunt measurements obtained by the $100 \%$ inspired oxygen and radioisotope methods in one centre, ${ }^{103}$ and between $100 \%$ oxygen and the multiple inert gas elimination technique (MIGET) in another, though only when right heart catheter data allowed appropriately high mixed venous oxygen content values to be used in the shunt equation for $100 \%$ oxygen. ${ }^{65}$ Contrast echocardiography was more sensitive than measurement of arterial blood gas tensions and chest radiography. ${ }^{105}$ Indirect comparisons between PAVM screens in neighbouring European HHT populations indicate that contrast echocardiography is also more sensitive than $100 \%$ inspired oxygen methods; contrast echocardiography generated a high diagnostic yield of $51 \%$ (many of whom did not have angiographi- cally detectable $\mathrm{AVMs}^{90}$ ) compared with $33 \%$ in a separate HHT population screened by $100 \%$ oxygen methods. ${ }^{42}$ It has therefore been suggested that contrast echocardiography may be an excessively sensitive technique, and this needs to be determined.

All non-invasive methods occasionally fail to detect PAVMs which are subsequently diagnosed by angiography (see table 3). More commonly the inverse is seen; an abnormally high shunt is detected by non-invasive methods but no shunt is seen at formal pulmonary artery catheter angiography. Nearly $40 \%$ of a total of 109 PAVMs identified by CT scanning were not detected at angiography ${ }^{88}$ and an abnormal transfer factor for carbon monoxide (TLCO), observed in a proportion of patients with PAVMs, often persists following apparently successful embolisation therapy. ${ }^{73}{ }^{75}$ It is presumed that lesions missed by formal pulmonary angiography (or responsible for the reduced transfer factors) were too small for detection (as in fig 1B) and will not be amenable to embolisation. When widespread they cause profound hypoxaemia, ${ }^{784954}$ but the clinical significance of smaller numbers of such PAVMs is unknown.

\section{Conclusions and recommendations}

Patients considered at risk of PAVMs because of suspicious symptoms, signs or radiological appearances should be investigated with at least measurement of arterial blood gas tensions and/or supine and erect oximetry, together with posterior-anterior and lateral chest radiographs. If there is still concern, at least one non-invasive method to assess the presence of PAVMs or degree of right-to-left shunting should be undertaken before formal pulmonary angiography is warranted; the choice of procedure is still likely to depend upon local experience. Shunt measurements are likely to be performed by $100 \%$ oxygen methods in respiratory units, nucleotide scanning in centres where facilities are available, and elsewhere by contrast echocardiography noting that this technique is likely to overestimate the number of patients with treatable lesions. When a shunt is detected but pulmonary angiography proves negative, the possibility of intracardiac shunting may need to be excluded by echocardiography.

Screening programmes to detect PAVMs in patients with HHT deserve separate consideration as these will often take place outside a hospital and can involve a large number of individuals. There is continuing debate regarding which screening methods should be used. It may therefore be worth selecting robust, easy to perform techniques. For example, the use of initial oximetry avoids the discomfort of arterial blood gas sampling and may be justified, particularly in children. The optimal screening intervals are unknown. Current recommendations to screen every 5-10 years, ${ }^{1}{ }^{106}$ or more frequently if the patient is approaching a period known to be associated with PAVM enlargement and rupture such as puberty $^{2107}$ or pregnancy, ${ }^{163}$ are rarely achieved. Lesions can develop over 2-3 years ${ }^{76}$ 
so even these regimes may be insufficiently frequent. The risks of PAVMs increase during pregnancy so it is particularly important to screen prior to or, if necessary, during pregnancy ${ }^{62}{ }^{63}$ since safe embolisation procedures can be carried out even in the third trimester, ${ }^{62}$ but it should be noted that desaturation due to right-to-left shunting may be masked by physiological factors during pregnancy. ${ }^{108}$ Although some authors have suggested that screening for PAVMs can be limited to individuals with particular genotypes, ${ }^{1}$ the current genetic data do not allow the risk of PAVMs to be confidently excluded and suggest that all HHT families should be offered screening ${ }^{106109}$ (see below).

TREATMENT OF PAVMS

Surgical resection was the only treatment available for PAVMs until recently and it caused significant morbidity. ${ }^{50} 71$ The advent of pulmonary artery embolisation ${ }^{110} 111$ altered the risk-benefit ratio of intervention markedly and coincided with a wider recognition of the risks of leaving asymptomatic PAVMs untreated (although such concerns were first raised nearly 50 years ago ${ }^{86}$ ). The hazards of intervention relate predominantly to the procedure, though removal of a low resistance shunt may rarely aggravate coincidental pre-existing pulmonary hypertension resulting from nonHHT pulmonary vascular pathogenic events. ${ }^{73} 76112113$

\section{Embolisation}

The embolisation techniques used to occlude the feeding vessels to PAVMs with thrombus are described elsewhere. ${ }^{73}{ }^{82} 114-116$ The thrombus organises on thrombogenic fibres associated with carefully positioned metallic coils, or as a result of blood stasis due to an occluding balloon. In one CT scan follow up series $96 \%$ of PAVMs regressed including $57 \%$ within four weeks of embolisation. ${ }^{88}$ The coil or balloon needs to be small enough to be sited distally to prevent occlusion of a feeder vessel which also supplies a normal capillary bed, but not too small to risk systemic embolisation through the PAVM $^{82115}$ or the development of collateral flow between the bronchial artery and distal pulmonary artery resulting in recanalisation of the PAVM. ${ }^{77}$ As a result, detachable coils and balloons have been developed. The choice of specific agent to initiate thrombus formation is a result of personal preference and experience of the operator. Balloons may be better for more distal placement ${ }^{77} 115$ but they carry the risk of deflation prior to permanent occlusion of the vessel. ${ }^{74} 76$ 117

Embolisation of PAVMs is generally safe (see table 4) and both safety and efficacy improve with experience ${ }^{7578116}$ as illustrated by the reduction in episodes of air embolism causing transient angina over recent years. All reports document dramatic improvements in the physiological extent of the shunt (table 4). ${ }^{65}$ Exercise capacity may improve even in patients who had not developed hypoxaemia on exertion. ${ }^{73}$ Lung volumes are generally preserved and there may be improved forced vital capacity if PAVMs had been acting as space occupying lesions. ${ }^{93}$ The reduction in TLCO often does not improve, ${ }^{73} 75$ presumably because it reflects the involvement of smaller vessels. Once embolised, the feeding artery to the PAVM usually remains occluded according to most series. A particular result in a recent series with a surprisingly high rate of recanalisation (and unusually half of the new feeder arteries being of bronchial artery supply ${ }^{77}$ ) may have been due to technical issues, alternative diagnostic methods, or a different patient population. However, it is well recognised that removal of a low resistance shunt may unmask or provoke the development of new PAVMs or new pulmonary artery feeder vessels to the treated lesion. As a result, a series of treatments several months apart may be required, and it is generally recommended that patients should remain under regular review. ${ }^{75} 7678$

Unfortunately, the firm clinical impression of a reduction in the occurrence of cerebral events following embolisation therapy has not yet been supported by adequate numerical data. Between $19 \%$ and $60 \%$ of patients with PAVMs treated by embolisation have residual shunts as measured directly or suggested by persistent hypoxaemia, ${ }^{75} 7678$ the figure rising to $73 \%$ when contrast echocardiography was used. ${ }^{87}$ Cerebrovascular complications have occurred in treated patients, including one cerebral abscess in the Hammersmith series, ${ }^{75}$ and two cerebrovascular accidents occurred amongst the seven patients with persistent PAVMs in the "large PAVM" Baltimore/Yale series (45 patients were initially treated). ${ }^{78}$ Embolisation of progressively smaller vessels has been adopted to reduce these risks, though technical issues limit the feasibility of embolisation, particularly with smaller vessels and diffuse disease.

\section{Surgery}

Surgical procedures have largely been supplanted by the embolisation techniques described above. ${ }^{119}$ In addition to the perioperative risks, there were concerns regarding loss of functioning lung in patients at risk of recurrent disease in non-resected lobes. Some reports demonstrated improved haemodynamics and oxygenation ${ }^{66}$ following surgery but physiological studies showed significant residual right-to-left shunts in many patients (table 4).

Surgical intervention may be appropriate in some situations since morbidity has been reduced with improved surgical techniques including the use of video assisted thoracoscopy ${ }^{120}$ which is helped by the subpleural location of many PAVMs. ${ }^{50}$ A strong case for surgical intervention by choice was proposed relatively recently ${ }^{74}$ based on poor embolisation data from a single institution, but the findings in this series are not representative of the results elsewhere. ${ }^{78}$ Surgical resection might be indicated for patients in whom a persistent right-to-left shunt (and embolic risk) persists following embolisation of all feasible vessels. ${ }^{88}$ Lung transplantation has been proposed for patients with diffuse disease, ${ }^{54}$ though for most 
Table 4 Treatment of PAVM in different series of patients. Series completion dates are given as the year of publication if not specified

\begin{tabular}{|c|c|c|c|c|c|c|c|c|c|c|c|}
\hline \multirow[b]{2}{*}{ Series years (reference) } & \multirow[b]{2}{*}{$\begin{array}{l}\text { No of } \\
\text { patients }\end{array}$} & \multirow[b]{2}{*}{$\begin{array}{l}\text { No of } \\
\text { PAVMS }\end{array}$} & \multirow[b]{2}{*}{ Mortality } & \multicolumn{4}{|c|}{ Complications } & \multirow{2}{*}{$\begin{array}{l}\text { Mean } \\
R-L \text { shunt } \\
\text { pre-post } R x\end{array}$} & \multirow[b]{2}{*}{$\begin{array}{l}\text { Residual } \\
\text { R-L shunt }\end{array}$} & \multirow[b]{2}{*}{$\begin{array}{l}\text { Follow up } \\
\text { (years) }\end{array}$} & \multirow[b]{2}{*}{$\begin{array}{l}\text { Complications } \\
\text { during follow up }\end{array}$} \\
\hline & & & & Pleurisy & $\begin{array}{l}\text { Paradoxical } \\
\text { embolism }\end{array}$ & $\begin{array}{l}\text { Balloon } \\
\text { deflation }\end{array}$ & Other & & & & \\
\hline \multicolumn{12}{|l|}{ Embolisation } \\
\hline \multicolumn{12}{|l|}{ Baltimore-Yale series } \\
\hline 1978-1980 (118) & 5 & 16 & 0 & $15 \%$ & $15 \%$ & $15 \%$ & - & - & - & $<2$ & $40 \%$ recur \\
\hline pre $1983(72)$ & 10 & 58 & 0 & $20 \%$ & - & several & $10 \%$ ang & 44 to $24 \%$ & - & - & - \\
\hline 1978-1987 (53) & 76 & 276 & 0 & $10 \%$ & $3 \%$ & $0 \%$ & $5 \%$ ang & - & - & - & - \\
\hline 1991-1992 (117) & 35 & 96 & 0 & $7 \%$ & $1 \%$ & $6 \%$ & $6 \%$ ang & - & - & $1-10$ & $1.3 \%$ recur \\
\hline $1978-1995(78) \dagger$ & 45 & 52 & 0 & $31 \%$ & $4 \%$ & - & $2 \%$ ang & - & $53 \% \Delta$ & - & $\begin{array}{l}15 \% \text { recur, } \\
4 \% \text { CVA }\end{array}$ \\
\hline \multicolumn{12}{|l|}{ Hammersmith series } \\
\hline 1984-1990(82) & 16 & 79 & 0 & $13 \%$ & - & - & $1 \mathrm{DVT}$ & 28 to $13 \%$ & - & - & - \\
\hline $1990-1995(114)$ & 6 & 28 & 0 & $7 \%$ & $0 \%$ & - & 1DVT & - & - & - & $12 \%$ recur \\
\hline $1987-1994(75)$ & 53 & $>200$ & 0 & $9 \%$ & $2 \%$ & $3 \%$ & $3 \%$ ang & 23 to $9 \%$ & $60 \%($ & $<4$ & $\begin{array}{l}2 \% \text { cerebral } \\
\text { abscess }\end{array}$ \\
\hline \multicolumn{12}{|l|}{ Other series } \\
\hline pre 1991 (116) & 19 & 58 & 0 & $26 \%$ & $2 \%$ & - & nil & - & - & & $10 \%$ recur \\
\hline 1986-1991 (73) & 8 & 22 & 0 & $25 \%$ & $0 \%$ & - & $\begin{array}{l}12 \% \\
\text { arryth }\end{array}$ & 25 to $13 \%$ & $100 \%$ & $<2$ & 一 \\
\hline 1990-1995 (76) & 32 & 92 & 0 & $9 \%$ & $4 \%$ & $2 \%$ & $2 \%$ arryth & 17 to $7 \%$ & $19 \% ®$ & mean 2 & $6 \%$ recur \\
\hline 1989-1994 (77) & 12 & 20 & 0 & $36 \%$ & - & - & nil & - & $73 \% \%^{\mathrm{TM}}$ & - & - \\
\hline 1994-1998 (87) & 7 & 14 & 0 & - & - & - & & - & - & - & $57 \%$ recur \\
\hline \multicolumn{12}{|l|}{ Surgery } \\
\hline $1897-1953(58)$ & 140 & - & $5 \%$ & & & & & & - & - & 1 out of 3 recur \\
\hline $1952-1967(56)$ & 16 & - & - & & & & & & - & $1-15$ & - \\
\hline pre $1958(50)$ & 239 & 212 & $5 \%$ & Minimal & data reported & & & & - & - & prog SOB \\
\hline pre $1963(71)^{\star}$ & 31 & 40 & $3 \%$ & & & & & & 1 out of 3 & - & - \\
\hline 1964-1992 (74) & $?$ & 12 & 0 & & & & & & 1 out of 1 & - & - \\
\hline \multicolumn{12}{|l|}{ Mayo Clinic } \\
\hline 1952-1966 (59) & 28 & - & 0 & & & & & & - & $1-12$ & $\begin{array}{l}1 \text { prog SOB, } \\
1 \text { CVA }\end{array}$ \\
\hline $1952-1972(52)$ & 36 & - & 0 & & & & & & 3 out of 3 & $1-12$ & $\begin{array}{l}4 \text { prog SOB, } \\
1 \text { CVA }\end{array}$ \\
\hline 1973-1984 (55) & 18 & - & 0 & & & & & & 5 out of 10 & $1-12$ & - \\
\hline
\end{tabular}

$\overline{\mathrm{DVT}}=$ deep venous thrombosis; ang = angina; arryth = arrhythmia; recur = recurrence; prog = progressive; SOB = shortness of breath; CVA = cerebrovascular accident.

${ }^{\star}$ Childhood series.

tAll lesions had feeding artery diameters of $8 \mathrm{~mm}$ or more.

Mean values for R-L shunt stated; residual shunt measured or indicated by ${ }^{\left(9{ }^{9 m}\right.}$ Tc scanning, ${ }^{\circledR} 100 \%$ inspired oxygen, ${ }^{\mathrm{TM}}$ contrast echocardiography and $\Delta$ persistent hypoxaemia as defined in reference 42 .

patients the untreated prognosis is unlikely to justify exposure to transplantation associated morbidity.

\section{Conclusions and perspective}

Retrospective series of patients with PAVMs that are generally symptomatic indicate that the risks associated with non-treatment ${ }^{5255} 59$ exceed those of any interventional regime (table 4). The overwhelming benefit of embolisation therapy compared with surgical resection is that it spares functioning lung in patients who are at risk of developing new lesions. Nevertheless, it is important to determine whether embolisation is able to prevent paradoxical emboli as satisfactorily as complete surgical excision in individuals where this would have been feasible. Further long term follow up data are required for all treated patients, probably stratified according to the degree of residual shunt, and distinguishing between individuals with and without HHT (the development of new PAVMs is less likely in the latter group).

Embolisation is currently recommended for all PAVMs with feeding arteries greater than $3 \mathrm{~mm}$ in diameter. ${ }^{54} 76^{121}$ This is based on technical issues and the diameters of feeding arteries associated with clinical strokes which in four patients ranged from $2.9 \mathrm{~mm}$ to $4.6 \mathrm{~mm} .{ }^{121}$ Some centres routinely treat feeding vessels between $2 \mathrm{~mm}$ and $3 \mathrm{~mm}$ in diameter. ${ }^{116}$

While feeding vessels of larger calibre will obviously pose the highest risk of embolic events, it has not been established that smaller vessels pose no risk. Such vessels would include those in angiography negative, shunt positive patients, particularly those detected by contrast echocardiography, and may concern a large proportion of patients with PAVMs as 13 of 31 feeding arteries were less than $3 \mathrm{~mm}$ in diameter in one survey of CT scans. ${ }^{96}$ It will be important to follow the clinical progress of these and equivalent cohorts to assess whether the screening methods are too sensitive for clinical use, or are defining a group of patients in whom particularly rigorous follow up is indicated. At present it seems reasonable to extend the recommendations for prophylactic antibiotic therapy from all patients in whom PAVMs are suspected to include patients in whom PAVMs have been treated, unless careful post-embolisation investigations indicate that the residual shunts have been abolished.

In view of the number of situations in which there is a lack of good longitudinal data on the outcome of patients with HHT, it is hoped that current national and international collaborative efforts will be extended to include such studies with agreed protocols, particularly in the areas highlighted in this section.

\section{Current understandings of mechanisms}

The identification of mutations in two genes which encode components of the receptor complexes for ligands of the TGF- $\beta$ superfamily indicates a role for these growth factors in HHT. In this section we present the 
currently available data that are directing future research into the understanding of the pathogenesis of this vascular disease. There remain considerable gaps in the mechanistic links between genomic mutations and the generation of the diseased blood vessels.

There are good clinical as well as scientific reasons for pursuing the study of the underlying molecular defects in HHT. Performing mutation analysis of endoglin (HHT1) and ALK-1 (HHT2) on a large number of patients should indicate whether specific mutations are related to particular phenotypes or complications, and further advance our understanding of the structure and function of these proteins and their contribution to the pathology of HHT. A molecular diagnostic test is currently under development and, once such a test is shown to be reliable, it will facilitate the identification of patients with HHT and the classification of families.

MOLECULAR GENETICS OF HHT

Linkage studies first identified a locus for HHT on chromosome $9^{122}{ }^{123}$ and suggested that a further gene existed. ${ }^{122}$ Additional families were used to map a second HHT locus to chromosome $12^{124} 125$ and it is likely that there is at least one more locus. ${ }^{126}$ A locus on 3 p 22 was suggested ${ }^{4}$ but was subsequently shown not to be the case. ${ }^{125}$ The mutated genes were identified as endoglin on chromosome $9^{4}$ and ALK-1 on chromosome $12 .{ }^{5}$

\section{Endoglin (HHT1)}

The gene for endoglin lies on the long arm of chromosome 9 in the interval predicted by linkage analyses. A number of mutations have now been characterised and are summarised in fig 3. ${ }^{409}{ }^{127-130}$ The mutations include deletions and insertions, missense mutations, and point mutations generating premature stop codons. Additional mutations are predicted in promoter or intronic regions. ${ }^{109}$ These considerations, and the fact that almost all mutations have been unique to a particular family, highlight the difficulties facing mutational screening programmes.

Not all mutations result in stable mRNA transcripts. ${ }^{109} 130$ Mutant proteins are rarely detectable and, if expressed at all, exist transiently within the cell and do not reach the cell surface (fig $3^{128}$ and unpublished observations). This leads to a decrease in the level of functional endoglin expressed on peripheral blood activated monocytes and umbilical vein endothelial cells in patients with HHT1. ${ }^{128}$ Quantification of the level of mature endoglin expressed using metabolic labelling and immunoprecipitation is being used to screen potential patients with HHT1 prior to mutation identification (unpublished data, presented in table 5). Affected members in 57 of $95 \mathrm{HHT}$ families tested had a mean endoglin level of $48 \%$ of normal (range $8-72 \%$ ) while nonaffected siblings in these families had a mean level of $105 \%$ (range $73-140 \%$ ). The normal levels of endoglin predicted in patients with HHT2 were confirmed in families in which ALK-1 mutations were identified; their levels were indistinguishable from normal individuals. Peripheral blood mononuclear cells (lymphocytes and monocytes) do not express significant levels of endoglin when first isolated but induction occurs if the monocyte fraction is activated by adherence and cell culture for 16-24 hours. ${ }^{128}{ }^{131}$ Levels are, however, 5-20 times lower than on human umbilical vein endothelial cells (HUVEC) where endoglin expression is abundant and constitutive. This

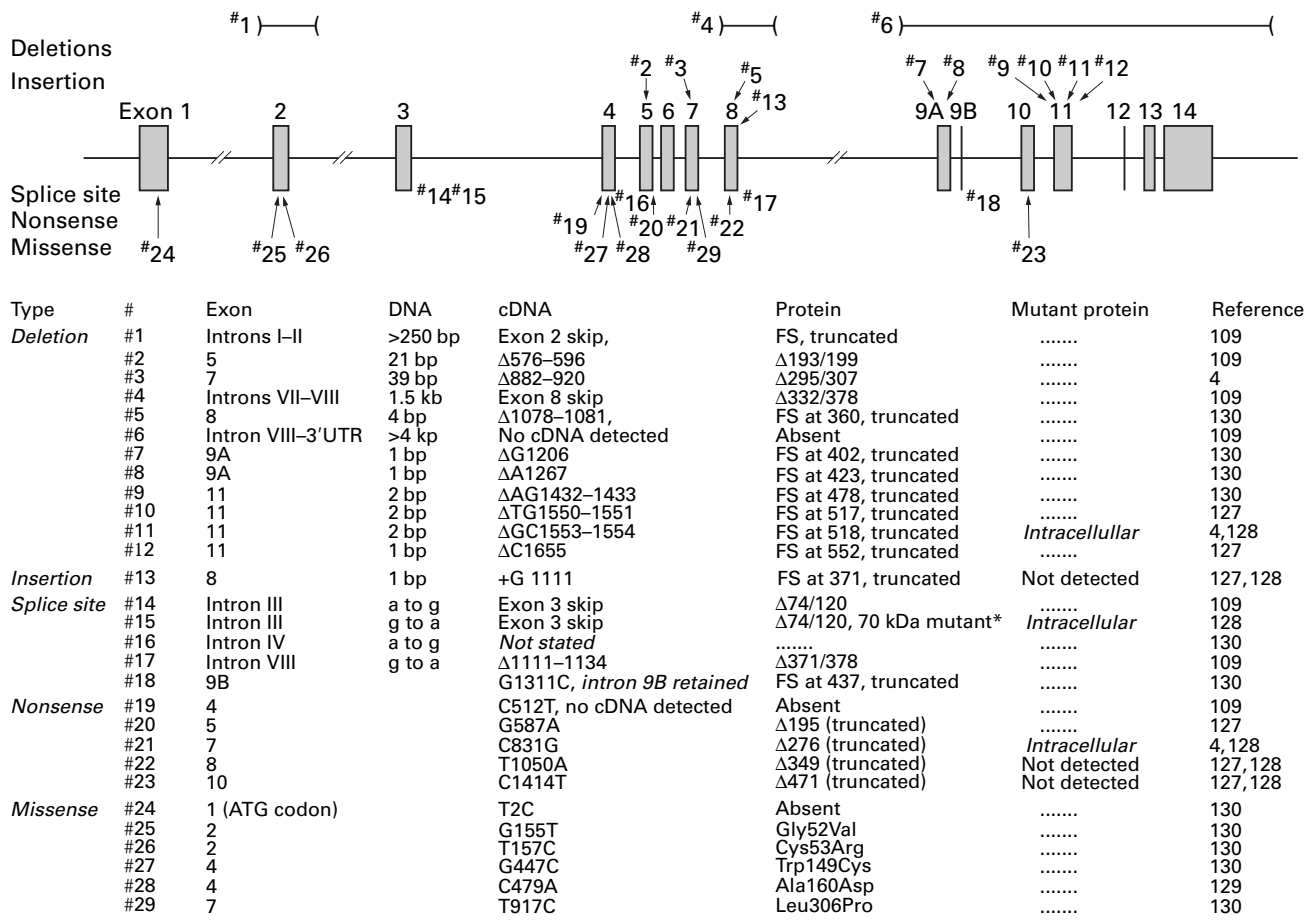

Figure 3 Summary of endoglin mutations. Intracellular refers to detection when transfected into COS cells. FS = frameshift; UTR $=$ untranslated region; $\Delta$ indicates deletion . 
Table 5 Analysis of endoglin levels in HHT families in relation to mutations detected

\begin{tabular}{|c|c|c|c|c|c|c|}
\hline & \multicolumn{2}{|c|}{ Endoglin level } & \multirow{2}{*}{$\begin{array}{l}\text { Cases } \\
\text { tested }\end{array}$} & \multirow[b]{2}{*}{ Predicted outcome } & \multicolumn{2}{|c|}{ Mutations detected } \\
\hline & Mean & Range & & & Endoglin & $A L K-1$ \\
\hline Non-affected siblings & $105 \%$ & $73-140 \%$ & 36 & Normal & 0 & 0 \\
\hline \multicolumn{7}{|c|}{ Clinically diagnosed HHT patients } \\
\hline Group A & $48 \%$ & $8-72 \%$ & 92 & HHT1 & 19 & 0 \\
\hline Group B & $101 \%$ & $72-137 \%$ & 38 & Non-HHT1 & 0 & 3 \\
\hline \multicolumn{7}{|c|}{ Newborns from HHT families } \\
\hline Group A & $47 \%$ & $26-61 \%$ & 15 & HHT1 & 9 & 0 \\
\hline \multirow[t]{2}{*}{ Group B } & $99 \%$ & $83-128 \%$ & 38 & Normal (if HHT1 family, $\mathrm{n}=19$ ) & $5^{\star}$ & 0 \\
\hline & & & & $\begin{array}{l}\text { Normal or HHT2 (if non-HHT1 } \\
\text { family, } \mathrm{n}=19 \text { ) }\end{array}$ & 0 & 2 \\
\hline
\end{tabular}

${ }^{\star}$ Mutation present in affected parent and absent from newborn.

Endoglin levels were measured on peripheral blood activated monocytes in patients and siblings and umbilical vein endothelial cells in neonates by metabolic labelling and immunoprecipitation. Levels are expressed relative to controls (spouses or age matched unrelated blood or umbilical cord samples) and, in the HHT family members, fell into two distinct groups as illustrated.

explains the smaller range of values observed for HUVEC from patients with HHT1 (26$61 \%$ ) and HHT2 or normal neonates (83$128 \%$ ) than for the activated monocytes (table 5).

These data also indicate that endoglin mutations are not affecting the normal allele, contrary to a previous proposal that the mutations were behaving as dominant negative alleles. ${ }^{127}$ We have also shown that vessels that appear to be normal in patients with HHT1 express reduced levels of endoglin in situ $(50 \%)$ compared with values seen in normal individuals and when compared with the endothelial cell marker PECAM-1. ${ }^{132}$

The next mechanistic question is whether the development of an arteriovenous malformation requires a "second hit" to inactivate the normal copy of endoglin, analogous to the situation proposed for tumour suppressor genes. ${ }^{4}$ This appears not to be the case as the ratio of endoglin to PECAM-1 was similar in the vascular lesions (cerebral and pulmonary AVMs) as in the other vessels in these patients. ${ }^{132}$ This suggests that the endoglin mutations are operating as null alleles causing haploinsufficiency.
ALK-1 (HHT2)

The HHT gene on chromosome 12 encodes a receptor for the TGF- $\beta$ superfamily, the activin receptor-like kinase 1 (ALK-1; also known as TSR 1$).{ }^{5}$ The mutations described in this gene are found in sequences encoding the extracellular, transmembrane, and kinase domains (fig 4). ${ }^{5133134}$ Their distribution, and the fact that some mutant alleles appeared to result in low to undetectable levels of transcript, indicate that this group of mutations may also result in functionally null alleles. ${ }^{133}$

GENOTYPE-PHENOTYPE CORRELATIONS

Locus heterogeneity: differences between endoglin and $A L K-1$ families

Prior to the molecular studies the fact that HHT was a heterogeneous disorder had not been fully appreciated. Occasional familial clustering of cerebral ${ }^{135} 136$ and pulmonary ${ }^{119}$ involvement had been described but it was not clear whether this represented chance occurrences in a disease in which only some members of an affected family developed any particular complication.

Even before mutations in endoglin on chromosome 9 and $A L K-1$ on chromosome 12 were

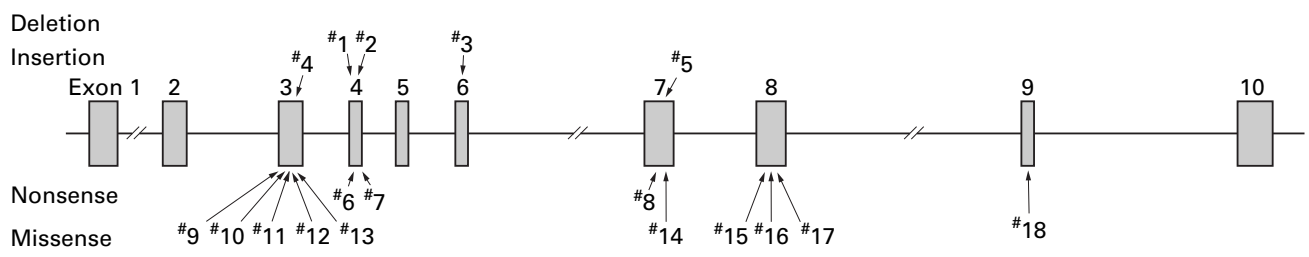

$\begin{array}{llc}\text { Type } & \# & \text { Exon } \\ \text { Deletions } & \# 1 & 4 \\ & \# 2 & 4 \\ \text { Insertions } & \# 3 & 6 \\ & \# 4 & 3 \\ \text { Nonsense } & \# 5 & 7 \\ & \# 6 & 4 \\ & \# 7 & 4 \\ \text { Missense } & \# 8 & 7 \\ & \# 9 & 3 \\ & \# 10 & 3 \\ & \# 11 & 3 \\ & \# 12 & 3 \\ & \# 13 & 3 \\ & \# 14 & 7 \\ & \# 15 & 8 \\ & \# 16 & 8 \\ & \# 17 & 8 \\ & \# 18 & 9\end{array}$

cDNA
$\Delta \mathrm{G} 400(1 \mathrm{bp})$
$\Delta \mathrm{G} 406-409$ (4 bp)
$\Delta 694-696$ (3 bp)
$140(1 \mathrm{bp})$
865 (1 bp)
G423A
G475T
C924A
G150T
G152A
G200A
C231G
A286G
G998T
C1120T
T1126G
G1232A
C1270A
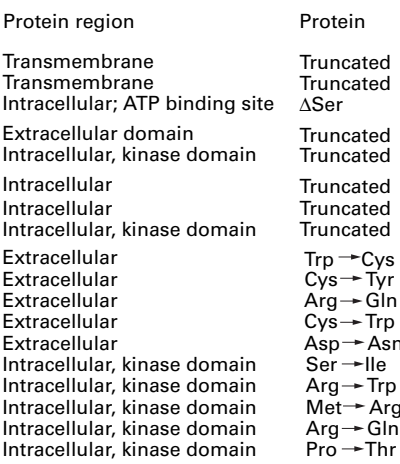

Reference
134
134
5
134
133
133
133
133
133
134
133
134
134
133
133
5
5
133

Figure 4 Overview of ALK-1 mutations. $\Delta$ indicates deletion. 
described, a flurry of reports signalled that there might be differences between families according to whether they were linked to the chromosome 9 locus or not. ${ }^{137-139}$ Once mutated genes were identified the search for phenotype-genotype correlations intensified. In essence, however, only two distinctions can be made at present-namely, that PAVMs are significantly more common in endoglin than non-endoglin HHT families ${ }^{1140}$ and that ALK-1 families tend to have milder disease with more cases of non-penetrance. ${ }^{5}$ PAVMs do not occur exclusively in endoglin families, however, ${ }^{109} 122$ and the phenotype of endoglin families can be mild for several generations before an affected family member presents with PAVMs. ${ }^{106} 109$ Thus, it is dangerous to apply these population statistics to individual cases.

There are anecdotal suggestions that CAVMs may also be more common in families with endoglin mutations but no evidence has been published. Finally, an HHT family unlinked to either endoglin or $A L K-1$ may have a predisposition towards hepatic involvement, ${ }^{126}$ but interpretation needs to be cautious since systematic hepatic screening of asymptomatic family members has not been repeated in other HHT populations.

\section{Specific mutations}

Phenotypic data are only available for 30 individuals with seven endoglin mutations (\#1, 2, $4,6,14,17,19$, fig 3). No significant differences between mutations or mutational types with respect to age of presentation, severity of nose bleeds, telangiectasia, or PAVMs have been identified. ${ }^{109}$ This would be predicted from a haploinsufficiency model. Each mutation accounted for a spectrum of disease severity in affected family members not entirely accounted for by age-related penetrance, ${ }^{109}$ highlighting the importance of additional modifiers of the HHT phenotype.

Genetic and environmental modifiers of the HHT phenotype

Clinical observations provide clues to several factors that may potentially influence the development of HHT lesions in patients, though undoubtedly more will be described. Defects in the coagulation cascade which could exacerbate a haemorrhagic tendency are often cited and are discussed in detail elsewhere, ${ }^{141}$ but they are rare and have not influenced clinical practice. Variations in fibrinolysis may also contribute to a haemorrhagic tendency: quenching excessive fibrinolysis using aminocaproic acid had beneficial effects in some ${ }^{23} 24$ but not all $^{25}$ of a handful of patients tested.

Less obvious at first sight is the importance of the patient's sex in a condition inherited as an autosomal dominant trait. Excluding neonates, women are more at risk of developing PAVMs $^{525355637576}$ and possibly hepatic involvement $^{33142}$ and cerebral haemorrhage. ${ }^{143}$ This may reflect a fundamental modification of the HHT vasculature by female hormones, or relate to haemodynamic changes during pregnancy. ${ }^{63}$ A role for direct hormonal influences is supported by the successful treatment of HHT related gastrointestinal bleeding using combined oestrogen-progesterone therapy, ${ }^{21} \mathrm{a}$ report of progesterone receptors in vessels of patients with $\mathrm{HHT}^{144}$ and variations in epistaxis during the menstrual cycle and menopause.$^{63}$ Haemodynamic changes can also exacerbate PAVMs, including the development of pulmonary hypertension as a result of mitral stenosis $^{145}$ or left ventricular dysfunction. ${ }^{146}$ Furthermore, cutaneous telangiectasia (known to be in a dynamic state in $\mathrm{HHT}^{147}$ ) have been observed to regress following successful pneumonectomy for PAVMs, ${ }^{80}{ }^{148}$ possibly due to a predicted fall in cardiac output though this was not documented.

MECHANICS: HOW TO GENERATE AN HHT

VESSEL - THE EXAMPLE OF PAVMS

The question as to whether any of the abnormal blood vessels in patients with HHT (telangiectases or larger arteriovenous malformations) represent true congenital malformations rather than an acquired lesion in intrinsically abnormal vessels has not been resolved. The majority of PAVMs present during teenage and adult life, suggesting that vascular remodelling is occurring. However, the presentation of PAVMs in childhood is well recognised 50525355859717578 and, although severe disease in two infants may have been due to homozygous HHT, the possibility of PAVMs arising during development cannot be ruled out.

As vascular lesions are associated with both HHT1 and HHT2, the potential role of both endoglin and ALK-1 needs to be considered. Both mutated genes encode proteins that are expressed predominantly in endothelial cells, which might explain why affected individuals are generally well apart from their vascular pathology. As there is only limited information available on ALK-1 we will discuss it first before concentrating on endoglin and the lesions with which it is particularly associated-namely, PAVMs.

\section{ALK-1: a serine/threonine kinase type I receptor} in search of a function

Members of the TGF- $\beta$ superfamily bind and signal through a heteromeric receptor complex composed of serine/threonine kinases in which the type II receptor generally binds ligand and phosphorylates the type I receptor which in turn signals through the recently identified cascade of Smad proteins. ${ }^{149} 150$ ALK-1 is a serine/threonine kinase type I receptor that can associate with either TGF- $\beta$-RII or activin-RII when co-transfected into COS cells (a transformed primate cell line), and can bind TGF- $\beta 1$ or activin, respectively, although with low affinity. ${ }^{151-153}$ Since this has not been demonstrated with endogenous receptors, ALK-1 is referred to as an orphan receptor as its physiological ligand has yet to be identified. The potential ligand might belong to another subgroup of the TGF- $\beta$ superfamily - namely, the bone morphogenetic proteins (BMPs), as activation of ALK-1 has recently been shown to trigger an intracellular Smad-1 pathway associated with signalling by BMPs. ${ }^{154}$ 
High levels of ALK-1 are found on human endothelial cells and in lung and placenta, both of which are highly vascular. ${ }^{151}{ }^{152}$ Rat ALK-1 was found to be most abundant in pulmonary blood vessel endothelium (all types) as well as on aorta, vena cava, and certain blood vessels of kidney, spleen, heart, and intestine. ${ }^{155}$ Lung expression increased fivefold in the early postnatal period, most probably reflecting an increase in the pulmonary vasculature. ${ }^{155}$ ALK-1 was also found on rat splenic macrophages and a murine bone marrow stromal cell line. ${ }^{156}$ This distribution has many parallels to that of endoglin. A more recent study in a murine model found that the distribution of ALK-1 was highest around eight days after conception at sites of vasculogenesis in both embryonic and extra-embryonic tissues, in giant trophoblast cells, and in the endothelial lining of blood vessels in the decidua. From days 9-12 ALK-1 was highest in blood vessels, lung mesenchyme, the submucosa of the intestine and stomach, and at sites of epithelialmesenchymal interactions. ${ }^{157}$ This pattern of expression of ALK-1 is very close to that of TGF- $\beta 1,{ }^{158}$ in keeping with a potential role in vascular development which may be confirmed in the ALK-1 null mice currently in development.

\section{Endoglin: an accessory protein of the TGF- $\beta$ receptor superfamily}

Endoglin was first identified in childhood leukaemia with a pre-B lymphocytic phenotype ${ }^{159}$ and was soon recognised as an endothelial cell marker (CD105) which is expressed on all types of vascular endothelium. ${ }^{160}{ }^{161}$ It is also present on bone marrow mononuclear cells of the preerythroblast lineage ${ }^{162}$ and on activated macrophages. ${ }^{131}$ The expression of endoglin is transiently increased in mesenchymal cells during embryonic development in association with cardiac valve formation, for example. ${ }^{163}$ Endoglin expression is also increased in mesenchymal cells in the human lung starting at eight weeks gestation and remains high at 20 weeks (unpublished observations), in keeping with a potential role in vascularisation of lining mesenchyme. In the adult endoglin is expressed on endothelium ${ }^{160}$ and placenta, ${ }^{164}$ with smooth muscle cell expression also described. ${ }^{165}$ Endoglin is upregulated on vascular endothelial cells in tumours, ${ }^{166}$ pathological skin lesions including psoriasis, and in response to UV irradiation. ${ }^{167168}$

Endoglin is a homodimeric membrane glycoprotein of apparent $\mathrm{Mr}=180000^{169} 170$ and has been shown first by chemical crosslinking in HUVECs and subsequently in fibroblasts to bind TGF- $\beta 1$ and TGF- $\beta 3$ but not TGF- $\beta 2 .{ }^{170-172}$ It can associate with TGF $\beta$-RII and TGF $\beta$-RI (ALK-5) ${ }^{173}{ }^{174}$ as indicated by immunoprecipitation of the TGF- $\beta 1$ affinity crosslinked complexes with antibodies to either endoglin or TGF $\beta$-RII. However, we have recently demonstrated that endoglin by itself does not bind $T G F-\beta 1 / \beta 3$ and therefore cannot be referred to as a receptor; it only behaves as such when associated with TGF $\beta$-RII. ${ }^{175}$

We have also observed that endoglin can bind other growth factors of the TGF- $\beta$ superfamily when associated with the different ligand binding receptors. For example, endoglin can bind activin or BMP-7 when cotransfected with activin RII; it will not bind BMP-7 via BMP-RII, however, indicating that these interactions are specific. It will also bind BMP-2 when associated with the ligand binding type I receptors, ALK-3 and ALK-6. ${ }^{175}$ These results suggest that endoglin might serve as an accessory protein for multiple kinase receptor complexes of the TGF- $\beta$ superfamily and that it could perform a different regulatory role in diverse cell types, according to the kinase receptors, ligands, and Smad mediators present.

When transfected into U937 monocytes or rat myoblasts, endoglin can modify certain TGF- $\beta 1$ (but not TGF- $\beta 2$ ) responses such as the inhibition of cell proliferation by downregulation of $c-m y c$, the increase in homotypic adhesion mediated by increased fibronectin production, and modulation of the fibrinolytic system by synthesis of plasminogen activator inhibitor-1. ${ }^{176} 177$ Conversely, antibodies and antisense oligonucleotides to endoglin added to first trimester trophoblast explants in culture stimulated the differentiation of trophoblasts into invasive cells, a process necessary for establishing fetal-maternal interactions and known to be inhibited by TGF- $\beta 1 / \beta 3$. ${ }^{178}$

Although a potential role for endoglin in regulating responses to ligands other than TGF- $\beta 1$ must be kept in mind while trying to elucidate the underlying mechanisms of HHT, it is clear that TGF- $\beta 1$ is an important regulator of vascular development. TGF- $\beta 1$ null mice showed a primary defect in yolk sac vasculogenesis and haematopoiesis which led to death at around day 10 in $50 \%$ of homozygous and $25 \%$ of heterozygous mice. ${ }^{179}$ The differentiation of endothelial cells was affected (rather than their initial appearance or outgrowth from yolk sac mesoderm), causing inadequate capillary formation and weak vessels with reduced cellular adhesiveness. Furthermore, TGF- $\beta 3$ null mice died soon after birth with extensive pleural haemorrhage and dilated and fragile pulmonary veins and capillaries. ${ }^{180} 181$ This suggests that TGF- $\beta 1$ and TGF- $\beta 3$ are both implicated in the development of lung vasculature and impairment of their usual function might contribute to the pathology of PAVMs.

With this information is it possible to propose why PAVMs develop? Endoglin is present from the earliest stages of pulmonary vascular development, and TGF- $\beta 1$ and TGF- $\beta 3$ are implicated in vasculogenesis ${ }^{180} 181$ and angiogenesis, ${ }^{182}$ both processes being critical in vessel development and maturation. ${ }^{183}$ In patients with HHT and reduced endoglin expression, vascular development is sufficiently normal for most individuals to have apparently normal pulmonary vasculature. The careful regulation of endoglin expression (and ALK-1) during development suggests, however, that their complete absence could be lethal, as seen 
in the potential homozygotes. ${ }^{12}{ }^{13}$ Current studies in null mice should resolve this issue.

If most vessels with $50 \%$ expression of endoglin develop normally, what additional factors cause some vessels to develop into PAVMs? Certain physiological or pathological conditions, including altered blood flow ${ }^{184-186}$ and hormonal changes, could be important. This would provide a partial explanation for why only a small proportion of endothelial cells expressing a mutant allele are involved in morphologically abnormal HHT vessels.

We would like to propose that reduced levels of functional endoglin results in blood vessels that are more susceptible to dilatation and remodelling. We have shown that the endothelium in a CAVM was partially disrupted and stretched out so that the density of important surface molecules was reduced. ${ }^{132}$ In addition, it may be recalled that TGF- $\beta 1$ plays a major role in wound repair. It is abundantly released by platelets and macrophages at sites of inflammation and injury, ${ }^{187-189}$ is upregulated by shear stress, ${ }^{190}$ and has been implicated in vascular repair processes. ${ }^{191}$ In tissue repair as well as in development, TGF- $\beta 1$ stimulates the growth of cells of mesenchymal origin. Furthermore, TGF- $\beta 1$ induces the synthesis of extracellular matrix proteins, their integrin receptors on the cell surface, and the protease inhibitors implicated in their degradation such as plasminogen activator inhibitor and tissue inhibitor of metalloproteases; it also downregulates the expression of matrix degrading enzymes such as collagenase. ${ }^{192} 193$ The net effect of TGF- $\beta 1$ is thus to stimulate matrix production and enhance interactions between cells and matrix and between endothelium, smooth muscle cells, and mesenchymal cells in the vessel wall. Vasodilatation, intravascular pressure, or shear stress can affect endothelial cell shape in vivo and could initiate remodelling in vessels with reduced levels of endoglin.

\section{Perspectives}

The abnormal vascular structures in HHT appear to develop because mutations in endoglin, ALK-1, and possibly other genes result in a dysregulated response to ligands of the TGF- $\beta$ superfamily which play complex and important roles in vascular development and repair. At present we cannot pinpoint the exact ligand(s) or manner in which normal vascular development or homeostasis is perturbed by these mutations. Potential ligands of the TGF- $\beta$ superfamily have diverse and often multiple effects that may influence the vasculature, effects which may be differentially regulated and fine tuned according to the exact amount of endoglin or ALK-1 present. Future developments are likely to include the identification of the precise TGF- $\beta$ family members involved in the disease, and of additional components of the pathogenic pathway which may be identified from finding mutations in new genes in other HHT families. In addition, clarification of the roles of normal and mutated endoglin and ALK-1 through cellular and animal models is expected.
The identification of a gene defect in an inherited disease leads to expectations of molecular therapies, particularly when the molecular mechanism appears to be stoichiometric insufficiency, amenable to replacement therapy. However, there are hazards in attempting to restore functional levels of a deficient protein in complex regulatory networks such as those in which ligands of the TGF- $\beta$ family are involved. It may be some time therefore before molecular manipulations of HHT can be applied to patients and, for the foreseeable future, conventional therapies are likely to be required.

Claire Shovlin has been supported by a Wellcome Trust Advanced Fellowship; Michelle Letarte is a Tery Fox Research Scientist of the National Institute of Canada, and is supported by research grants from the Heart and Stroke Foundation and the Medical Research Council of Canada.

The cases illustrated in fig $2 \mathrm{~B}$ and fig 3 were investigated at the Royal Infirmary of Edinburgh. The authors thank Dr David Lamb and Professor Bill MacNee for fig 2B. For fig 3, Dr Kieran McBride performed the angiography, Dr Patricia Tweedale the shunt measurements, and Dr Micheal Sudlow gave permission to report the case. The authors are grateful to Dr Patricia Tweedale, Dr Kees Westermann, and Dr Bob White for helpful discussions, and to Dr Gillian Wallace and Dr Patricia Tweedale for manuscript review. They also thank the staff of the Erskine Medical Library, University of Edinburgh and colleagues who provided them with manuscripts prior to their publication. Most countries have self-help groups for patients with HHT: UK: Telangiectasia Self-Help Group, 39 Sunny Croft, Downley, High Wycombe, Bucks. HP13 5UQ, UK.

USA: HHT Foundation International, PO Box 8087, New Haven, CT 06530, USA.

1 Haitjema T, Westermann CJJ, Overtoom TTC, et al. Hereditary hemorrhagic telangiectasia (Osler-WeberRendu disease): new insights in pathogenesis, complications, and treatment. Arch Intern Med 1996;156:714-9.

2 Guttmacher AE, Marchuk DA, White RI. Hereditary hemorrhagic telangiectasia. N Engl f Med 1995;333:918-24.

3 Braverman IM, Keh A, Jacobson BS. Ultrastructure and three-dimensional organization of the telangiectases of hereditary hemorrhagic telangiectasia. F Invest Dermatol 1990;95:422-7.

4 McAllister KA, Grogg KM, Johnson DW, et al. Endoglin, a TGF- $\beta$ binding protein of endothelial cells, is the gene for hereditary haemorrhagic telangiectasia type 1 . Nature Genet 1994;8:345-51.

5 Johnson DW, Berg JN, Baldwin MA, et al. Mutations in the activin receptor-like kinase 1 gene in hereditary haemorrhagic telangiectasia type 2. Nature Genet 1996;13:189-95.

6 Braverman IM, Keh-Yen A. Ultrastructure and threeBraverman IM , Keh-Yen A. Ultrastructure and three-
dimensional reconstruction of several macular and papular dimensional reconstruction of several macular and

7 MacNee W, Buist T, Finlayson NDC, et al. Multiple microscopic pulmonary arteriovenous connections in the lungs presenting as cyanosis. Thorax 1985;40:316-8.

8 Plauchu H, de Chadarévian J-P, Bideau A, et al. Age-related clinical profile of hereditary hemorrhagic telangiectasia in an epidemiologically recruited population. Am F Med Genet 1989;32:291-7

9 Guttmacher AE, McKinnon WC, Upton MD. Hereditary hemorrhagic telangiectasia: a disorder in search of the genetics community. Am f Med Genet 1994;52:252-3.

10 Jesserun GAJ, Kamphuis DJ, van der Zande FHR, et al. Cerebral arteriovenous malformations in the Netherlands Antilles: High prevalence of hereditary hemorrhagic Antilles: High prevale malformations. Clin Neurol Neurosurg 1993;95:193-8.

11 Kjeldsen AD, Vase P, Green A. Hereditary haemorrhagic telangiectasia: a population-based study of prevalence and mortality in Danish patients. F Int Med 1999;245:31-9.

12 Snyder LH, Doan CA. Clinical and experimental studies in human inheritance: is the homozygous form of multiple human inheritance: is the homozygous form of mult
telangiectasia lethal? $\mathcal{F}$ Lab Clin Med 1944;29:1211-6.

13 Higgins C, Wexler L. Clinical and angiographic features of pulmonary arteriovenous fistulas in children. Radiology 1976;119:171-5

14 Muller J-Y, Michailov T, Izrael V, et al. Maladie de RenduOsler dans une grande famille saharienne. La Nouvelle Presse Med 1978;7:1723-5

15 Vase P, Lorentzen M. Histological findings following oestrogen treatment of hereditary haemorrhagic telangiectasia. A controlled double-blind investigation $f$ Laryngol Otol 1983;97:427-9.

16 Parkin JL, Dixon JA. Argon laser treatment of head and neck vascular lesions. Otolaryngol Head Neck Surg 1985;93: neck vasce.

17 Vickery CL, Kuhn FA. Using the KTP/532 laser to control epistaxis in patients with hereditary hemorrhagic telangiectasia. South Med $\mathcal{f}$ 1996;89:78-80. 
18 Shapshay SM, Oliver P. Treatment of hereditary hemorrhagic telangiectasia by Nd-YAG laser photocoagulation. rhagic telangiectasia by Nd-YAC
Laryngoscope 1984;94:1554-6.

Laryngoscope 1984;94:1554-6.
19 Ulsø C, Vase P, Stoksted P. Long-term results of dermatoplasty in the treatment of hereditary haemorrhagic telangiectasia. F Laryngol Otol 1983;97:223-6.

20 Halpern M, Turner AF, Citron BP. Hereditary hemorrhagic telangiectasia. An angiographic study of abdominal visceral angiodysplasias associated with gastrointestinal hemorrhage. Radiology 1968;90:1143-9.

21 Van Cutsem E. Oestrogen-progesterone, a new therapy of bleeding gastrointestinal vascular malformations. Acta Gastro-Enterologica Belg 1993;56:2-10.

22 Sargeant I, Loizou LR, Rampton DA, et al. Laser ablation of upper gastrointestinal vascular ectasias: long term results. Gut 1993;34:470-5.

23 Kwaan HC, Astrup T. Demonstration of cellular fibrinolytic activity by the histochemical fibrin slide technique. $L a b$ Invest 1967:17:140-5.

24 Saba HI, Morelli GA, Logrono LA. Treatment of bleeding in hereditary hemorrhagic telangiectasia with aminocaproic acid. N Engl f Med 1994:330:1789-90.

25 Korsenik JR, Topazion MD, White RI. Treatment of bleeding in hereditary hemorrhagic telangiectasia with aminocaproic acid. $N$ Engl F Med 1994;331:1236.

26 Childers RW, Ranniger K, Rabinowitz M. Intrahepatic arteriovenous fistula with pulmonary vascular obstruction in Osler-Rendu-Weber disease. Am f Med 1967;43:304-12.

27 Caselitz M, Wagner S, Chavan A, et al. Clinical outcome of transfemoral embolisation in patients with arteriovenous malformations of the liver in hereditary haemorrhagic telangiectasia (Weber-Rendu-Osler disease). Gut 1998;42. 123-6.

28 Bjøro K, Schrumpf E, Elgjo K, et al. Monstous ascites in hereditary haemorrhagic telangiectasia. Scand $\mathcal{F}$ Gastroenterol 1995;30:92-4.

29 Okabe H, Ishibashi H, Kimura H, et al. Rendu-Osler-Weber disease with portosystemic encephalopathy. Fap $\mathcal{f} \mathrm{Med}$

30 Buscarini E, Buscarini L, Civardi G, et al. Hepatic vascular malformations in hereditary hemorrhagic telangiectasia: imaging findings. Am F Radiol 1994;163:1105-10.

31 Göthlin JH, Nordgård $\mathrm{K}$, Jonsson $\mathrm{K}$, et al. Hepatic telangiectasia in Osler's disease treated with arterial embolization. Report of two cases. Eur $\mathcal{F}$ Radiol 1982;2:2730 .

32 Bourgeois N, Delcour C, Deviere J, et al. Osler-WeberRendu disease associated with hepatic involvement and high output heart failure. F Clin Gastroenterol 1990;12:2368 .

33 Bauer T, Britton P, Lomas D, et al. Liver transplantation for hepatic arteriovenous malformation in hereditary haemorhepatic arteriovenous malformation in hereditar

34 Vase I, Vase P. Ocular lesions in hereditary haemorrhagic telangiectasia. Acta Ophthalmol 1979;57:1084-90.

35 Brant AM, Schachat AP, White RI. Ocular manifestations in hereditary hemorrhagic telangiectasia (Rendu-OslerWeber disease). Am f Ophthalmol 1989;107:642-6.

36 Cooke DAP. Renal arteriovenous malformation demonstrated angiographically in hereditary haemorrhagic telangiectasia (Rendu-Osler-Weber disease). $7 \mathrm{R} \mathrm{Soc} \mathrm{Med}$ 1986;79:744-6.

37 Kurnik PB, Heymann WR. Coronary artery ectasia associated with hereditary hemorrhagic telangiectasia. Arch Intern Med 1989;149:2357-9.

38 Hieshima GB, Cahan LD, Berlin MS, et al. Calvarial, orbita and dural vascular anomalies in hereditary hemorrhagic telangiectasia. Surg Neurol 1977;8:263-7.

39 Forker EL, Bean WB. Retinal arteriovenous aneurysm in hereditary hemorrhagic telangiectasia. Arch Intern Med 1963;111:778-83.

40 Shovlin CL, Guttmacher AE, Buscarini E, et al. Diagnostic criteria for hereditary haemorrhagic telangiectasia (RenduOsler-Weber syndrome). Am f Med Genet (in press).

41 Suresh CG, Coupe MO, Jegarajah S. Recurrent cerebra abscesses 20 years before recognition of multiple pulmonary arteriovenous malformations. Br f Clin Pract 1995;49: 105-6.

42 Haitjema T, Disch F, Overtoom TTC, et al. Screening family members of patients with hereditary hemorrhagic telangiectasia. Am f Med 1995;99:519-24.

43 Pikus HJ, Beach ML, Harbaugh RE. Microsurgical treatment of arteriovenous malformations: analysis and comparison with stereotactic radiosurgery. $\mathcal{f}$ Neurosurg 1998;88:641-6.

44 Turiman F, Massoud TF, Viñuela F, et al. Correlation of the angioarchitectural features of cerebral arteriovenous malformations with clinical presentation of hemorrhage. Neurosurgery 1995;37:856-62.

45 Willinsky RA, Lasjaunias P, Terbrugge K, et al. Multiple cerebral arteriovenous malformations (AVMs). Review of our experience from 203 patients with cerebral vascular lesions. Neuroradiology 1990;32:207-10

46 Ter Berg JWM, Dippel DWJ, Habbema JDF, et al. Unruptured intracranial arteriovenous malformations with hereditary haemorrhagic telangiectasia. Neurosurgical
treatment or not? Acta Neurochir (Wien) 1993;121:34-42.

47 Ter Berg JWM, Overtoom TMD, Ludwig J, et al. Detection of unruptured familial intracranial aneurysms by intraaffected families. Neuroradiology 1987;29:272-6.

48 Cooley DA, McNamara DG. Pulmonary telangiectasia: report of a case proven by pulmonary biopsy. $\mathcal{F}$ Thorac Surg 1954;27:614-622.
49 Hales MR. Multiple small arteriovenous fistulas of the lungs. Am 7 Pathol 1956;32:927-43.

50 Bosher LH, Blake A, Byrd BR. An analysis of the pathologic anatomy of pulmonary arteriovenous aneurysms with paricular reference to the applicability of local excision. Surgery 1959;45:91-104

51 Anabtawi IAN, Ellison RG, Ellison LT. Pulmonary arteriovenous aneurysms and fistulas. Ann Thorac Surg 1965;1: 277-85.

52 Dines DE, Arms RA, Bernatz PE, et al. Pulmonary arteriovenous fistulas. Mayo Clin Proc 1974;49:460-5.

53 White RI, Lynch-Nyhan A, Terry P, et al. Pulmonary arteriovenous malformations: techniques and long-term outcomes of embolotherapy. Radiology 1988;169:663-9.

54 Hughes JMB. Intrapulmonary shunts: coils to transplantaion. f R Coll Phys 1994;28:247-53.

55 Dines DE, Seward JB, Bernatz PE. Pulmonary arteriovenous fistulas. Mayo Clin Proc 1983;58:176-81.

56 Sluiter-Eringa H, Orie NGM, Sluiter HJ. Pulmonary arteriovenous fistula. Diagnosis and prognosis in noncomplainant patients. Am Rev Respir Dis 1969;100:177-88.

57 Vase P, Holm M, Arendrup H. Pulmonary arteriovenous fistulas in hereditary hemorrhagic telangiectasia. Acta Med Scand 1985;218:105-9.

58 Stringer CJ, Stanley AL, Bates RC, et al. Pulmonary arteriovenous fistula. Am F Surg 1955;89:1054-80.

59 Gomes MR, Bernatz PE, Dines DE Pulmonary arteriovenous fistulas. Ann Thorac Surg 1969;7:582-93.

60 Muri JW. Arteriovenous aneurysm of the lung. Am f Surg 1955;89:265-71

61 Burke CM, Safai C, Nelson DP, et al. Pulmonary arteriovenous malformations: a critical update. Am Rev Respir Dis 1986;134:334-9.

62 Ference BA, Shannon TM, White RI, et al. Life threatening pulmonary hemorrhage with pulmonary arteriovenous malformations and hereditary hemorrhagic telangiectasia. Chest 1994;106:1387-92.

63 Shovlin CL, Winstock AR, Peters AM, et al. Medical complications of pregnancy in hereditary haemorrhagic telangiectasia. $O 7$ Med 1995;88:879-87.

64 Waldhausen JA, Abel FL. The circulatory effects of pulmohary arteriovenous fistulas. Surgery 1966;59:76-80.

65 Andrivet P, Lofaso F, Carette M-F, et al. Haemodynamics and gas exchange before and after coil embolization of pulmonary arteriovenous malformations. Eur Respir 7 1995;8: 1228-30.

66 Moyer JH, Glantz G, Brest AN. Pulmonary arteriovenous fistulas. Physiologic and clinical considerations. Am f Med 1948;32:417-35.

67 Whyte MKB, Hughes JMB, Jackson JE, et al. Cardiopulmonary response to exercise in patients with intrapulmonary vascular shunts. $\mathcal{F}$ Appl Physiol 1993;75:321-8.

68 Román G, Fisher M, Perl DP, et al. Neurological manifestations of hereditary hemorrhagic telangiectasia (RenduOsler-Weber disease): report of 2 cases and review of the literature. Ann Neurol 1978;4:130-44.

69 Press OW, Ramsey PG. Central nervous system infections associated with hereditary hemorrhagic telangiectasia. $\mathrm{Am}$ f Med 1984;77:86-92

70 Yater WM, Finnegan J, Giffin HM. Pulmonary arteriovenous fistula (varix). $\mathcal{F} A M A$ 1949;141:581-9.

71 Shumacker HB, Waldhausen JA. Pulmonary arteriovenous fistulas in children. Ann Surg 1963;158:713-20.

72 Terry PB, White RI, Barth $\mathrm{KH}$, et al. Pulmonary arteriovenous malformations: physiologic observations and results of balloon embolisation. $N$ Engl f Med 1983;308: $1197-200$.

73 Pennington DW, Gold WM, Gordon RL, et al. Treatment of pulmonary arteriovenous malformations by therapeutic embolization. Am Rev Respir Dis 1992;145:1047-51.

74 Puskas JD, Allen MS, Moncure AC, et al. Pulmonary arteriovenous malformations: therapeutic options. Ann Thorac Surg 1993;56:253-8.

75 Dutton JAE, Jackson JE, Hughes JMB, et al. Pulmonary arteriovenous malformations: results of treatment with coil embolisation in 53 patients. AfR 1995;165:1119-25.

76 Haitjema TJ, Overtoom TTC, Westermann CJJ, et al. Embolisation of pulmonary arteriovenous malformations: results and follow-up in 32 patients. Thorax 1995;50:71923.

77 Sagara K, Miyazono N, Inoue H, et al. Recanalization after coil embolotherapy of pulmonary arteriovenous ismations: study of long term outcome and mechfor recanalization. AfR 1998;170:727-30.

78 Lee DW, White RI, Egglin TK, et al. Embolotherapy of large (2) sults. Ann Thorac Surg 1997;64:930-40.

79 Lincoln MJ, Shigeoka JW. Pulmonary telangiectasia without hypoxemia. Chest 1988;93:1097-8.

80 Stork WJ. Pulmonary arteriovenous fistulas. AfR 1955;74: 441-54.

81 Martinez FJ, Villanueva A, Pickering R, et al. Spontaneous hemothorax. Report of six cases and review of the literature. Medicine 1992;71:354-68.

82 Jackson JE, Whyte MKB, Allison DJ, et al. Coil embolization of pulmonary arteriovenous malformations. Cor Vasa 1990;32:191-6.

83 Swanson DL, Dahl MV. Embolic abscesses in hereditary hemorrhagic telangiectasia. 7 Am Acad Dermatol 1991;24: 580-3.

84 Mohler ER, Monahan B, Canty MD, et al. Cerebral abscess associated with dental procedure in hereditary haemorrhagic telangiectasia.Lancet 1991;338:508-9. 
85 Chan P. Antibiotic prophylaxis for patients with hereditary hemorrhagic telangiectasia. 7 Am Acad Dermatol 1992;26: $282-3$.

86 Lindskog GE, Liebow A, Kausel H, et al. Pulmonary arteriovenous aneurysm. Ann Surg 1950;132:591-610.

87 Andersen PE, Kjeldsen AD, Oxhøj H, et al. Embolotherapy for pulmonary arteriovenous malformations in patient with hereditary haemorrhagic telangiectasia (Rendu-OslerWeber syndrome). Acta Radiol 1998;39:723-6.

88 Remy J, Remy-Jardin M, Wattinne L, et al. Pulmonary arteriovenous malformations: evaluation with $\mathrm{CT}$ of the chest before and after treatment. Radiology 1992;182:809-16.

89 Thompson RD, Jackson J, Peters AM, et al. Sensitivity and specificity of radioisotope right-left shunt measurements and pulse oximetry for the early detection of pulmonary arteriovenous malformations. Chest 1999;115:109-13.

90 Kjeldsen A. Epidemiology and clinical aspects of hereditary haemorrhagic telangiectasia. PhD thesis, Odense, 1997.

91 Robin ED, Laman D, Horn BR, et al. Platypnea related to orthodeoxia caused by true vascular lung shunts. $N$ Engl $\mathcal{F}$ Med 1976:294:941-3.

92 Ueki J, Hughes JMB, Peters AM, et al. Oxygen and ${ }^{99 m}$ TcMAA shunt estimations in patients with pulmonary arteriovenous malformations: effects of changes in posture and lung volume. Thorax 1994;49:327-31.

93 Chilvers ER, Whyte MKB, Jackson JE, et al. Effect of percutaneous transcatheter embolization on pulmonary function, right-to-left shunt, and arterial oxygenation in patients with pulmonary arterio

94 Nickerson BG, Sarkisian C, Tremper K. Bias and precision of pulse oximeters and arterial oximeters. Chest 1988;93: 515-7.

95 Tweeddale PM, Douglas NJ. Accuracy of Biox IIA ear oximeter. Thorax 1981;36:708-9.

96 Remy J, Remy-Jardin M, Giraud F, et al. Angioarchitecture of pulmonary arteriovenous malformations: clinical utility of pulmonary arteriovenous malformations: clinical utility
of three-dimensional helical CT. Radiology 1994;191:65764 .

97 Halbsguth A, Schulze W, Ungeheuer E, et al. Pitfalls in the CT diagnosis of pulmonary arteriovenous malformations. $\mathcal{F}$ Comput Assist Tomogr 1983;7:710-2.

98 Gutierrez FR, Glazer HS, Levitt RG, et al. NMR imaging of pulmonary arteriovenous fistulae. F Comput Assist Tomogr 1984;8:750-2.

99 Berggren SM. The oxygen deficit of arterial blood caused by non-ventilating parts of the lung. Acta Physiol Scand 1942; 4(suppl II):7-92.

100 Mellemgaard K, Lassen NA, Georg J. Right-to-left shunt in normal man determined by the use of tritium and krypton 85. F Appl Physiol 1962;17:778-82.

101 Genovesi MG, Tierney DF, Taplin GV, et al. An intravenous radionuclide method to evaluate hypoxemia caused by abnormal alveolar vessels: limitation of conventional techniques. Am Rev Respir Dis 1976;114:56-65.

102 Strauss HW, Hurley PJ, Rhodes BA, et al. Quantification of right-to-left transpulmonary shunts in man. $\mathcal{F}$ Lab Clin Med 1969;74:597-607.

103 Chilvers ER, Peters AM, George P, et al. Quantification of right to left shunt through pulmonary arteriovenous malformations using ${ }^{99} \mathrm{Tc}^{\mathrm{m}}$ albumin microspheres. Clin Radiol 1988;39:611-4.

104 Shub C, Tajik AJ, Seward JB, et al. Detecting intrapulmonary right-to-left shunt with contrast echocardiography. Mayo Clin Proc 1976;51:81-4.

105 Barzilai B, Waggoner AD, Spessert C, et al. Twodimensional contrast echocardiography in the detection and follow-up of congenital pulmonary aerteiovenous malformations. Am f Cardiol 1991;68:1507-10.

106 Shovlin CL, Hughes JMB. Hereditary hemorrhagic telangiectasia. N Engl f Med 1996;334:330-1.

107 Kjeldsen A, Vase P, Oxhoj H. Hereditary haemorrhagic telangiectasia. $N$ Engl f Med 1996;334:331.

08 Hughes JMB, Shovlin CL, Simonds AK. Pulmonary disease and cor pulmonale. In: Oakley $\mathrm{C}$, ed. Heart disease in pregnancy. London: BMJ Publishing Group, 1997: 180200.

109 Shovlin CL, Hughes JMB, Scott J, et al. Characterization of endoglin and identification of novel mutations in hereditary hemorrhagic telangiectasia. Am f Human Genet 1997; 61:68-79.

110 Porstmann W. Therapeutic embolization of arteriovenous pulmonary fistulas by catheter technique. In: Kelop O, ed. Current concepts in pediatric radiology. Berlin: Springer, 1977: 23-31.

111 Taylor BG, Cockerill EM, Manfredi F, et al. Therapeutic embolization of the pulmonary artery in pulmonary arteriovenous fistula. Am 7 Med 1978;64:360-5.

112 Trell E. Pulmonary hypertension in congenital shun lesions. Observations in a right heart catheterization material, with particular reference to occurrence, natural history and prognostic implications in adolescence and adulthood. Acta Med Scand 1972;S535:3-26.

113 le Roux BT, Gibb BH, Wainwright J. Pulmonary arteriovenous fistula with bilharzial pulmonry hypertension. $B$ Heart f 1970;32:571-4

114 Hartnell GG, Allison DT. Coil embolization in the treatment of arteriovenous malformations. F Thorac Imaging 1989;4:81-5.

115 White RI, Pollack JS, Wirth JA. Pulmonary arteriovenous malformations: diagnosis and transcatheter embolotherapy. malformations: diagnosis and transcathe

116 Remy-Jardin M, Wattinne L, Remy J. Transcatheter occlusion of pulmonary arterial circulation and collateral supply: failures, incidents, and complications. Radiology 1991;180:

117 Pollak JS, Egglin TK, Rosenblatt MM, et al. Clinical results of transvenous systemic embolotherapy with a neuroradiologic detachable balloon. Radiology 1994;191:47782.

118 Barth KH, White RI, Kaufman SL, et al. Embolotherapy of pulmonary arteriovenous malformations with detachable balloons. Radiology 1982;142:599-606.

119 Hughes JMB, Allison DJ. Pulmonary arteriovenous malformations: the radiologist replaces the surgeon. Clin Radiol 1990;41:297-8.

120 Watanabe N, Munakata Y, Ogiwara M, et al. A case of pulmonary arteriovenous malformation in a patient with brain abscess successfully treated with video-assisted thoracoscopic resection. Chest 1995;108:1724-7.

121 White RI, Pollak JS. Pulmonary arteriovenous malformations: diagnosis by three-dimensional helical CT, a breakthrough without contrast media. Radiology 1994; 191:613-4.

122 Shovlin CL, Hughes JMB, Tuddenham EGD, et al. A gene for hereditary haemorrhagic telangiectasia maps to chromosome 9q3. Nature Genet 1994;6:205-9.

123 McDonald MT, Papenberg KA, Ghosh S, et al. A disease locus for hereditary haemorrhagic telangiectasia maps to chromosome 9q33-34. Nature Genet 1994;6:197-204.

124 Vincent P, Plauchu H, Hazan J, et al. A third locus for hereditary haemorrhagic telangiectasia maps to chromosome 12q. Hum Mol Genet 1995;4:945-9.

125 Johnson DW, Berg JN, Gallione CJ, et al. A second locus for hereditary hemorrhagic telangiectasia maps to chromosome 12. Genome Res 1995;5:21-8.

126 Piantanida M, Buscarini E, Dellavecchia C, et al. Hereditary haemorrhagic telangiectasia with extensive liver involvement is not caused by either HHT1 or HHT2. $\mathcal{F}$ involvement is not caused benet 1996;33:441-3.

127 McAllister KA, Baldwin MA, Thukkani AK, et al. Six novel mutations in the endoglin gene in hereditary hemorrhagic telangiectasia type I suggest a dominant-negative
effect of receptor function. Hum Mol Genet 1995;4:1983-5.

128 Pece N, Vera S, Cymerman U, et al. Mutant endoglin in hereditary hemorrhagic telangiectasia type I is transiently expressed intracellularly and is not a dominant negative. $\mathcal{F}$ Clin Invest 1997;100:2568-79.

129 Yamaguchi H, Azuma $\mathrm{H}$, Shigekiyo $\mathrm{T}$, et al. A novel missense mutation in the endoglin gene in hereditary hemorrhagic telangiectasia. Thromb Haem 1997;77:243-7.

130 Gallione CJ, Klaus DJ, Yeh EY, et al. Mutation and expression analysis of the endoglin gene in hereditary hemorrhagic telangiectasia reveals new alleles. Human Mutat 1998;11:286-94.

131 Lastres P, Martin-Perez J, Langa C, et al. Regulated expression on human macrophages of endoglin, an Arg-Gly-Asp-containing surface antigen. Eur $\mathcal{F}$ Immunol 1992;22:393-7.

132 Bourdeau A, Paquet M-E, Meschino W, et al. Endoglin expression is reduced on normal vessels but still detectable on cerebral arteriovenous malformations in a newborn diagnosed with hereditary haemorrhagic telangiectasia type . Submitted for publication

133 Berg JN, Gallione CJ, Stenzel TJ, et al. The activin receptor-like kinase 1 gene: genomic structure and mutations in hereditary haemorrhagic telangiectasia. Am F Hum Genet 1997;61:60-7.

134 Klaus DJ, Gallione CJ, Anthony K, et al. Novel missense and frameshift mutations in the activin receptor-like kinase-1 gene in hereditary hemorrhagic telangiectasia. Human Mutation, Mutations in Brief Online 1998; \#164.

135 Lesser BA, Wendt D, Miks VM, et al. Identical twins with hereditary hemorrhagic telangiectasia concordant for cerebrovascular arteriovenous malformations. Am $\mathcal{F} \mathrm{Med}$

136 King CR, Lovrien EW, Reiss J. Central nervous system arteriovenous malformations in multiple generations of a family with hereditary hemorrhagic telangiectasia. Clin Genet 1977;12:372-81

137 Heutink P, Haitjema T, Breedveld GJ, et al. Linkage of hereditary haemorrhagic telangiectasia to $9 \mathrm{q} 34$ and evidence for locus heterogeneity. I Med Genet 1994;31: 933-6.

138 McAllister KA, Lennon F, Bowles-Biesecker B, et al. Genetic heterogeneity in hereditary haemorrhagic telangiectasia: possible correlation with clinical phenotype. 7 Med Genet 1994;31:927-32.

139 Porteous MEM, Curtis A, Williams O, et al. Genetic heterogeneity in hereditary haemorrhagic telangiectasia. $\mathcal{F}$ Med Genet 1994;31:925-6.

140 Berg JN, Guttmacher AE, Marchuk DA, et al. Clinical heterogeneity in hereditary haemorrhagic telangiectasia: are pulmonary arteriovenous malformations more common in families linked to endoglin? $f \mathrm{Med}$ Genet 1996;33:256-7.

41 Shovlin CL. Molecular defects in rare bleeding disorders: hereditary haemorrhagic telangiectasia. Thromb Haem 1997;78:145-50.

142 Martini GA. The liver in hereditary haemorrhagic teleangiectasia: an inborn error of vascular structure with multiple manifestations: a reappraisal. Gut 1978;19:531-7.

143 Graf C, Perrett G, Torner J. Bleeding from cerebral arteriovenous malformations as part of their natural history. 7 Neurosurg 1983;58:331-7.

144 Richtsmeier W, Weaver G, Streck W, et al. Estrogen and progesterone receptors in hereditary hemorrhagic tel-
angiectasia. Otolaryngol Head Neck Surg 1984;92:564-70. 
145 Chow L-C, Chow W-H , Ma K-F. Pulmonary arteriovenous malformation. Progressive enlargement with replacement of the entire right middle lobe in a patient with

concomitant mitral stenosis. Med F Aust 1993;158:632-4.
Hughes JMB. Pulmonary arteriovenous malformations in 6 Hughes JMB. Pulmonary arteriovenous malformations in hereditary hemorrhag

147 Bean W. Notes on the natural history of vascular spiders in healthy persons. Arch Intern Med 1960;106:35-8

148 Moyer J, Ackerman A. Hereditary hemorrhagic telangiectases associated with pulmonary arteriovenous fistula in two members of one family. Ann Intern Med 1948;29:775-802.

149 Massague J. TGF $\beta$ signaling: receptors, transducers and MAD proteins. Cell 1996:85:947-50.

150 Heldin C-H, Miyazono K, ten Dijke P. TGF- $\beta$ signalling from cell membrane to nucleus through SMAD proteins. Nature 1997;390:465-71.

151 Attisano L, Carcamo J, Ventura F, et al. Identification of human activin and TGF $\beta$ type I receptors that form heterhuman activin and TGF $\beta$ type I receptors that form heter671-80.

152 ten Dijke P, Ichijo H, Franzén P, et al. Activin receptor-like kinases: a novel subclass of cell-surface receptos with predicted serine/threonine kinase activity. Oncogene 1993;8: 2879-87.

153 ten Dijke P, Yamashita H, Ichijo H, et al. Characterization of type I receptors for transforming growth factor- $\beta$ and activin. Science 1994;264:101-3.

154 Macias-Silva M, Hoodless PA, Tang S, et al. Specific activation of Smad1 signalling pathways by the BMP7 type receptor, ALK2. F Biol Chem 1998;273:25628-36.

155 Panchenko M, Mikhail P, Williams MC, et al. Type I receptor serine-threonine kinase preferentially expressed in
pulmonary blood vessels. Am F Physiol 1996;270:L547-58.

156 Wu X, Robinson C, Fong H, et al. Cloning and characterisation of the murine activin receptor like kinase-1 (ALK-1) sation of the murine activin receptor like kinase-1 (ALK-1)

157 Roelen B, van Rooijen M, Mummery C. Expression of ALK-1, a type 1 serine/threonine kinase receptor, coincides with sites of vasculogenesis and angiogenesis in early with sites of vasculogenesis and angiogenesis in early mouse $418-30$.

158 Dickson K, Philip A, Warshawsky H, et al. Specific binding of endocrine transforming growth factor- $\beta 1$ to vascular endothelium. F Clin Invest 1995;95:2539-5

159 Quackenbush EJ, Letarte M. Identification of several cell surface proteins of non-T, non-B acute lymphoblastic leukemia by using monoclonal antibodies. F Immunol 1985 134:1276-85.

160 Gougos A, Letarte M. Identification of a human endothelial cell antigen with monoclonal antibody $44 \mathrm{G} 4$ produced against a pre-B leukemic cell line. 7 Immunol 1988;141: 1925-33.

161 Letarte M, Greaves A, Vera S. CD105 (endoglin) cluster report. In: Schlossman S et al, eds. Leukocyte typing V: White cell differentiation antigens. Oxford: Oxford University Press, 1995: 1756-9.

162 Bühring H-J, Müller CA, Letarte M, et al. Endoglin is expressed on a subpopulation of immature erythroid cells

163 Qu R, Silver M, Letarte M. Distribution of endoglin in early human development reveals high levels on endocardial cushion tissue mesenchyme during valve formation. Cell Tissue Res 1998;292:333-43.

164 St-Jacques S, Forte M, Lye SJ, et al. Localization of endoglin, a transforming growth factor- $\beta$ binding protein, and of CD44 and integrins in placenta during the first trimester of pregnancy. Biol Reprod 1994;51:405-13.

165 Adam PJ, Clesham GJ, Weissberg PL. Expression of endoglin mRNA and protein in human vascular smooth muscle cells. Biochem Biophys Res Commun 1998;247:33-7.

166 Thorpe PE, Burrows FJ. Antibody-directed targeting of the vasculature of solid tumors. Breast Cancer Res Treat 1995;36:237-51.

167 Wang JM, Kumar S, van Agthoven AJ, et al. Irradiation induces up-regulation of E9 protein (CD105) in human induces up-regulation of E9 protein (CD105) in humal

168 Wang JM, Kumar S, Pye D, et al. A monoclonal antibody detects heterogeneity in vascular endothelium of tumours detects heterogeneity in vascular endothelium of

169 Gougos A, Letarte M. Primary structure of endoglin, an RGD-containing glycoprotein of human endothelial cells. $f$ Biol Chem 1990;265:8361-4.
170 St-Jacques S, Cymerman U, Pece N, et al. Molecular characterization and in situ localization of murine endoglin reveal that it is a transforming growth factor- $\beta$ binding protein of endothelial and stromal cells. Endocrinology 994;134:2645-57.

171 Cheifetz S, Bellón T, Calés C, et al. Endoglin is a component of the transforming growth factor- $\beta$ receptor system in human endothelial cells. F Biol Chem 1992;267:19027-30.

172 Bellón T, Corbi A, Lastres P, et al. Identification and expression of two forms of the human transforming growth factor- $\beta$-binding protein endoglin with distinct cytoplasmic regions. Eur F Immunol 1993;23:2340-5.

173 Yamashita H, Ichijoro H, Grimsby S, et al. Endoglin forms a heteromeric complex with the signaling receptors for ransforming growth factor- $\beta$. F Biol Chem 1994;269:19952001.

174 Zhang H, Shaw ARE, Mak A, et al. Endoglin is a component of the transforming growth factor (TGF) $-\beta$ receptor complex of human pre-B leukemic cells. f Immunol 1996;156:565-73.

175 Pece Barbara N, Wrana JL, Letarte M. Endoglin is an accessory protein that interacts with the signaling receptor complex of multiple members of the TGF- $\beta$ superfamily. $\mathcal{F}$ Biol Chem 1999;274:584-94.

176 Lastres P, Letamendía A, Zhang H, et al. Endoglin modulates cellular responses to TGF- $\beta 1$. F Cell Biol 1996;133: 1109-21.

177 Letamandía A, Lastres P, Botella LM, et al. Role of endogin in cellular responses to transforming growth factor- $\beta$. F Biol Chem 1998;273:33011-9.

178 Caniggia I, Taylor CV, Ritchie JWK, et al. Endoglin regulates trophoblast differentiation along the invasive pathway in human placental villous explants. Endocrinology 1997; 138:4977-88.

179 Dickson MC, Martin JS, Cousins FM, et al. Defective haematopoeisis and vasculogenesis in transforming growth factor- $\beta 1$ knock out mice. Development 1995;121:1845-54.

180 Proetzel G, Pawlowski S, Wiles M, et al. Transforming growth factor- $\beta 3$ is required for secondary palate fusion. Nature Genet 1995;11:409-14.

181 Kaartinen V, Voncken JW, Schuler C, et al. Abnormal lung development and cleft palate in mice lacking TGF- $\beta 3$ indicates defects of epithelial-mesenchymal interaction. Nature Genet 1995;11:415-21.

182 Koh GY, Kim S-J, Klug MG, et al. Targeted expression of transforming growth factor- $\beta 1$ in intracardiac grafts promotes vascular endothelial cell DNA synthesis. $\mathcal{F}$ Clin Invest 1995;95:114-21

183 Folkman J, D'Amore PA. Blood vessel formation: what is its molecular basis? Cell 1996;87:1153-5.

184 Clark ER, Clark EL. Microscopic observations on the extra-endothelial cells of living mammalian blood vessels. Am $\mathcal{F}$ Anat 1940;66:2-49.

185 Langille BL, Bendeck MP, Keeley FW. Adaptations of carotid arteries of young and mature rabbits to reduced carotid blood flow. Am f Physiol 1989;256:H931-99.

186 Cho A, Courtman DW, Langille BL. Apoptosis (programmed cell death) in arteries of the neonatal lamb. Circ Res 1995;76:168-75.

187 Derynk R, Jarrett JA, Chen EY, et al. Human transforming growth factor- $\beta$ complementary DNA sequence and expression in normal and transformed cells. Nature

88 Assoian RK, Fleurdelys BE, Stevenson HC, et al. Expression and secretion of type beta transfoming growth factor by activated human macrophages. Proc Natl Acad Sci USA 1987;84:6020-4.

189 Sporn MB, Roberts AB, Wakefield LM, et al. Some recent advances in the chemistry and biology of transforming growth factor-beta. $\mathcal{F}$ Cell Biol 1987;105:1039-45.

190 Ohno M, Cooke JP, Dzau VJ, et al. Fluid shear stress induces endothelial transforming growth factor beta-1 transcription and production. F Clin Invest 1995;95:13639.

191 Madri JA, Bell L, Merwin JR. Modulation of vascular cell behaviour by transforming growth factors $\beta$. Mol Reprod 1992;32:121-6.

192 Ignotz R, Endo T, Massague J. Regulation of fibronectin and type I collagen mRNA levels by transforming growth factor beta. 7 Biol Chem 1987;262:6443-6.

193 Edwards D, Murphy G, Reynolds J, et al. Transforming growth factor beta modulates the expression of collagenase and metalloproteinase inhibitor. EMBO $\mathcal{F}$ 1987;6:1899904. 